\title{
LOS ORÍGENES DE LA PRENSA LIBERAL: EL CASO DEL PERIÓDICO POLÍTICO Y MERCANTIL DE LA VILLA DE REUS (1813-1814)
}

\author{
Josep Fàbregas Roig* \\ Universitat Rovira i Virgili
}

RESUMEN: El decreto de noviembre de 1810, de libertad de imprenta, aprobado por las Cortes de Cádiz, facilitó la aparición de un conjunto de periódicos de ideología progresista. El 4 de octubre de 1813 se publicaba en Reus el Periódico político y mercantil de la Villa de Reus, un referente de la prensa liberal de inicios del siglo XIX. Sus noticias se referían al proceso constitucional español, al desarrollo de la guerra contra los franceses y a informaciones de tipo comercial. Su editor fue el prestigioso médico Jaume Ardévol.

Palabras clave: Prensa, Guerra Independencia, periódico liberal, libertad de imprenta, Jaume Ardévol.

\section{THE ORIGINS OF LIBERAL PRESS: THE CASE STUDY OF PERIÓDICO POLÍTICO Y MERCANTIL DE LA VILLA DE REUS (1813-1814)}

ABSTRACT: The decree of November 1810, on freedom of the press, approved by the Court of Cadiz, facilitated the emergence of a set of progressive ideology journals. On October $4^{\text {th }} 1813$, the Periódico político y mercantil de la Villa de Reus, a reference in the early nineteenth century liberal press, was published in Reus. Its news referred to the Spanish constitutional process, the development of the war against the French and commercial information. Its editor was the prestigious doctor Jaume Ardévol.

Keywords: Press, Peninsular War, liberal newspaper, freedom of the press, Jaume Ardévol.

\footnotetext{
* Miembro del Grupo de Investigación Consolidado de la Universidad Rovira i Virgili, Ideologías y Sociedad en la Cataluña Contemporánea (ISOCAC). Investigador en el proyecto (CSO201231206 Relaciones dinámicas entre mortalidad y fecundidad en las primeras fases de la Transición Demográfica).
} 


\section{Las Cortes de Cádiz y la libertad de prensa}

El siglo XIX se inició con la convulsión que para España representó la invasión del ejército napoleónico y el consiguiente estallido de la guerra de la Independencia. La ocupación militar, que desde el punto de vista social y económico fue funesta, facilitó la ruptura de la tradicional estructura económica, política y administrativa que representaba el Antiguo Régimen.

La guerra de la Independencia despertó el espíritu patriótico de la población y la prensa escrita tuvo una gran influencia en su difusión. Fue en aquel contexto cuando, sobre la base de la libertad de imprenta, contemplada en la Constitución de Cádiz, comenzó a surgir una prensa independiente. En ella se combinaban impresos tanto de tendencia liberal, siguiendo los nuevos cánones, como de ideología servil o absolutista, con inclinación al rey y a la Iglesia. Por otro lado, se publicaban periódicos afrancesados que -obviamente- defendían los intereses del invasor.

Hasta ese momento, la prensa se había caracterizado por la dependencia respecto al Estado que, en determinadas circunstancias, aplicaba la censura, como acaeció en febrero de 1791, cuando se suspendieron las publicaciones periódicas, con la excepción de la Gazeta de Madrid, el Mercurio y el Diario de Madrid.

Como bien sabemos, la pasividad de las instituciones de gobierno ante la ocupación francesa hizo que las movilizaciones populares adquirieran protagonismo. Durante los primeros meses de guerra, se constituyeron las juntas provinciales. El 25 de setiembre de 1808, en Aranjuez, se formó la Junta Suprema Central, que asumió la representación de la nación. La actividad política de la Junta se prolongó hasta que el decreto del 29 de enero de 1810 dio por concluidas sus funciones y se creó un Consejo de Regencia. Entre sus facultades estaba nombrar y cesar a los ministros, y designar los empleos civiles y militares, aunque carecía de iniciativa legal y tampoco podía excusar la observancia de las leyes ni interpretarlas. ${ }^{1}$

Desde su instauración se sucedieron hasta cuatro Regencias, la última de las cuales inició su actuación el 21 de marzo de 1813. La primera estaba formada por cinco miembros, nombrados por la Junta Suprema: Pedro de Quevedo y Quintano, obispo de Orense, como presidente; Francisco de Saavedra, Secretario de Estado y Hacienda; el capitán general Francisco Javier Castaños y Aragoni; el teniente general de marina Antonio de Escaño y, en representación de los territorios de América, Esteban Fernández de León, quien por no ser americano fue sustituido por el jurista mexicano, de origen vasco, Miguel de Lardizábal y Uribe. $^{2}$

1. ARTOla, GalleGO, M. "Cortes y constitución de Cádiz". En ESCUDERO, José A. (dir.). Cortes y Constitución de Cádiz, 200 años. Madrid: Espasa Libros, 2011, pp.3-19.

2. FLAQUER MONTEQUI, R. "El ejecutivo en la revolución liberal". En ARTOLA GALLEGO, M. (ed.) Las Cortes de Cádiz. Madrid: Marcial Pons, 2003, pp. 37-65. Con relación al 
El 17 de junio, el conde de Toreno y el canónigo Guillermo Hualde, en nombre de los diputados representantes de las juntas provinciales, solicitaron a la Regencia la convocatoria de unas Cortes extraordinarias, petición que tuvo el apoyo de los vocales de la Junta de Cádiz. Con un país ocupado por los invasores, con una monarquía secuestrada en Francia, indefectiblemente las Cortes se convertirían en el referente de la soberanía de la Nación. ${ }^{3}$

El 24 de setiembre de 1810 se reunieron por vez primera en la Isla de León. El Diario de Sesiones, al referirse al acto inaugural, ofreció la relación de diputados asistentes. Junto a los del resto de la nación, se encontraban los representantes catalanes: Felip Amat (noble, residente en Cervera), Ramon Sans i Barutell (noble, representante por Barcelona), Joan del Valle (diputado suplente por Cataluña, representante de Girona), Plàcid de Montoliu (noble, representante por Tarragona), Francesc de Papiol (presbítero en Vilanova i la Geltrú), Francesc Morrós i Cibila (párroco de Igualada), Josep Vega i Sentmenat (noble y delegado por Cervera), Fèlix Aytés (párroco de Agramunt), Ramon Utgés (catedrático de la Universidad de Cervera), Salvador Vinyals (villa de Terrassa), Jaume Creus (canónigo de la Seu d'Urgell), Ramon de Lladós (presbítero, representante de Talarn), Josep Antoni de Castellarnau (noble, diputado por Tarragona), Ramon Llàtzer de Dou (canciller de la Universidad de Cervera), Antoni de Capmany y Francesc Calvet (abogado y delegado por Girona). ${ }^{4}$

obispo de Orense, Pedro de Quevedo, Miguel Artola en su conocida obra Los orígenes de la España Contemporánea. Madrid: Instituto de Estudios Políticos, 1975, pp. 453 y 454, manifiesta que no acudiría a prestar el juramento para reconocer la soberanía de la nación y acabaría presentando la renuncia como presidente y diputado.

3. CUENCA TORIBIO, J. M. La Guerra de la Independencia: un conflicto decisivo (18081814). Madrid: Ediciones Encuentro, 2008, pp. 162 y 163.

4. Archivo Histórico de Tarragona (AHT). Manual Notarial de Francisco Salas Soler, 18101813. Poder de los diputados representantes de la Provincia de Cataluña en las Cortes Generales, firmado ante el notario Francisco Salas y Soler en Tarragona el 2 de agosto de 1810.

Diario de sesiones de las Cortes Generales y Extraordinarias: del 24 de septiembre de 1810 hasta el 20 de septiembre de 1813. Núm.1. Sesión del 24 de septiembre de 1810. Madrid: Imprenta de J. A. García, 1870-1874 pp. 1 y 2. Gazeta: colección histórica. Agencia Estatal del BOE. Gazeta extraordinaria de la Regencia de España é Indias. Núm. 74. Jueves 27 de septiembre de 1810, pp. 723-726. Consultado el 18/02/2014 de http://www.boe.es/buscar/gazeta.php. El 24 de octubre juró el cargo el abogado Felip Aner de Esteve (Junta Superior del Corregimiento de Talarn), el 29 José Espiga y Gadea, canónigo de la catedral de Lérida y el 11 de noviembre, Fernando Navarro (Tortosa). Durante el año 1811 también lo hicieron Joan Baptista Serres y Juan de Suelves, Marqués de Tamarit.

Con relación al nombramiento de diputados catalanes ver también MOLINER PRADA, A. La guerra del Francès a Catalunya segons el diari de Raimon Ferrer. Barcelona: Universitat Autònoma de Barcelona, 2010, pp. 261-263. SÁNCHEZ CARCELÉN, A. "Eclesiásticos catalanes y las Cortes de Cádiz". Anuario de Historia de la Iglesia. Vol. 19. (2010), pp. 119-140. GARCíA LEÓN, J. M. Los Diputados Doceañistas. Una aproximación al estudio de los Diputados de las Cortes Generales y Extraordinarias (1810-1813). Cádiz: Quorum Editores, 2012. PIÑA HOMS, R. "Los Diputados catalanes y Mallorquines". En ESCUDERO, José A. (dir.). Cortes y Constitución... pp. 308-333. 
A las nueve de la mañana, los diputados presentes, acompañados por el Consejo de Regencia, se dirigieron a la iglesia parroquial de San Pedro y San Pablo de la Isla de León donde participaron de la celebración eucarística que ofició Luís de Borbón, cardenal de Scala y arzobispo de Toledo. Después de la lectura del Evangelio, Pedro de Quevedo hizo una oración exhortatoria, y a continuación el Secretario de Estado y de Gracia y Justicia, Nicolás María de Sierra, leyó la fórmula de juramento, confirmada por todos los diputados que, en grupos de dos, colocaron las manos encima de los Santos Evangelios. El acto, reproducido en El juramento de las Cortes de Cádiz por el pintor José Casado del Alisal, concluyó con el canto del himno Veni Sancti Espiritus y el Te Deum. ${ }^{5}$ A continuación, la comitiva se trasladó al escenario donde se desarrollarían las sesiones. José Manuel Cuenca apunta que una parte significativa de los 95 diputados que acudieron -42 titulares y 53 suplentes-comprendió que había llegado la hora de la verdad respecto a sus ideas y deseos sobre el futuro del país. Los clasifica en tres grupos según su ideología: para los de tendencia liberal, la mirada al pasado inmediato les mostraba cómo se iban superando los obstáculos que impidieron, durante cerca de dos años, recorrer el camino que conducía al punto en que se encontraban; los que tenían una predisposición conservadora, conocidos como reaccionarios, eran conscientes de que, a tenor de lo ocurrido durante el mandato de la Junta Central y del Consejo de Regencia, el triunfo de su pensamiento no seria fácil; por último, los diputados que no participaban de ninguna de las opciones eran conscientes de la circunstancia que vivían y del carácter novedoso de los acontecimientos que se avecinaban. Liberales y reaccionarios pensaban que las Cortes serían el escenario en que se dirimiesen dos nociones de España, de su pasado y, sobre todo, de su porvenir. ${ }^{6}$

Una vez instaladas las Cortes, se procedió a la elección del presidente y, en segunda votación, por cincuenta votos contra cuarenta y cinco, fue elegido el religioso barcelonés Ramon Llàtzer de Dou, que fue rector de la Universidad de Cervera. ${ }^{7}$ Los diputados representaban diversos grupos sociales; sobre un total de 306 delegados que ocuparon escaño durante los años que duró la legislatura el grupo más numeroso, con unos 174, más de la mitad, correspondería a los comisionados de profesiones liberales y funcionarios estatales; 60 eran letrados, 55 funcionarios públicos, 16 profesores universitarios, 4 escritores y 2 médicos; Juan Sisinio Pérez Garzón incluye en este conjunto a 37 militares que, aunque pertenecientes a la nobleza, ejercían cargos públicos. El sector eclesiástico ocu-

5. Diario de sesiones de las Cortes Generales y Extraordinarias: dieron principio el 24 de setiembre de 1810 y terminaron el 20 de setiembre de 1813. Madrid: Imprenta de Juan Antonio García, 1870-1874. Núm. 1. Sesión del día 24 de septiembre de 1810, pp. 1 y 2 y Gazeta: colección histórica. Gazeta extraordinaria de la Regencia de España é Indias. Núm. 74. Jueves 27 de septiembre de 1810, pp. 723-726.

6. CUENCA TORIBIO, J. M. La guerra..., pp. 187 y 188.

7. Diario de Sesiones de las Cortes Generales y Extraordinarias. Núm. 1. Sesión del día 24 de septiembre de 1810 , p. 3. 
pó casi una tercera parte de los asientos; nobleza, comerciantes y propietarios completaban la asamblea. ${ }^{8}$

En febrero de 1811, dada la intranquilidad en la que se vivía por la proximidad de las tropas francesas que bloqueaban la Isla de León, las Cortes Generales y Constituyentes se trasladaron a Cádiz, donde, en el Oratorio de San Felipe Neri, desarrollaron las tareas legislativas, hasta que el 14 de septiembre de 1813 cerraron las sesiones. El día 25, en el mismo lugar, iniciaron su tarea las Cortes Ordinarias. A mediados de octubre, a causa de la fiebre amarilla, los diputados se trasladaron nuevamente a San Fernando, desde donde partirían hacia Madrid. En la capital de la nación, legislaron hasta mayo de 1814, momento en que fueron disueltas. ${ }^{9}$

Las Cortes y la Constitución que elaboraron, promulgada el 19 de marzo de 1812, introducirían nuevos conceptos en la vida política española: soberanía nacional, libertad, igualdad..., que cerrarían el período absolutista y abrirían las puertas al Estado liberal. A pesar de todo no se puede afirmar que fuera una constitución democrática: concedía a la Corona importantes atribuciones en el orden ejecutivo, dentro de un estado fuertemente centralizado; no reconocía el sufragio directo ni auténticamente universal, al excluir a las mujeres y a los criados domésticos; no garantizaba los derechos de reunión y de asociación; mantenía la confesionalidad del estado y no contemplaba la libertad de cultos. ${ }^{10}$ Manuel Moreno, intentando desmitificarla, la califica de utópica, alejada de la realidad, con unas leyes que configuraban la existencia de un Estado imaginario imposible de llevar a la práctica. Una de las consecuencias más inmediatas fue la interminable lista de leyes, decretos y reglamentos que tuvieron que redactarse para completarla. Incluso las nuevas ideas de libertad, patria, nación, pueblo, ciudadanía..., recogidas en ella, fueron producto más de la

8. PÉREZ GARZÓN, J. S. Las Cortes de Cádiz: el nacimiento de la nación liberal, 18081814. Madrid: Síntesis, 2007, pp. 213 y 214.

9. BELDA, J.; LABRA, R. de. Las Cortes de Cádiz en el Oratorio de San Felipe. Madrid: Imprenta del Fortanet, 1912, p. 4.

Con relación a las epidemias de fiebre amarilla consultar MELLADO, B. Historia de la epidemia padecida en Cádiz el año de 1810... Cádiz: Imprenta de Bartolomé Niel, 1811. También en ARÉJULA, J. M. de. Breve descripción de la Fiebre Amarilla padecida en Cádiz y pueblos comarcanos en 1800, en Medina sidonia, 1801, en Málaga en 1803 y en esta misma plaza y en otras varias del reino en 1804. Madrid: Imprenta Real, 1806. CARRILLO, J. L. Juan Manuel de Aréjula (1755-1830): estudio sobre la fiebre amarilla. Madrid: Ministerio de Sanidad y Consumo, 1986. CABAL, M. "Medidas adoptadas por la Junta de Sanidad del Principado ante la posible invasión peninsular de la fiebre amarilla existente en Cádiz y Real Isla de León en el siglo XVIII al XIX". Boletín del Instituto de Estudios Asturianos. Núm. 126 (abril-junio 1988), pp. 409-428. VÁZQUEZ DE QUEVEDO, F."La fiebre amarilla en los hospitales militares de Santander en 1814". Los cántabros. Núm. 2 (2008), pp. 62-65. FIGUERA VON WICHMANN, E. "Las enfermedades más frecuentes a principios del siglo XIX y sus tratamientos". En TORRES AURED, M. L (coord.) Los Sitios de Zaragoza. Alimentación, enfermedad, salud y propaganda. Zaragoza: IFC 2009, pp. 151-171.

10. VARELA SUANZES-CARPEGNA, J. Política y Constitución en España (1808-1978). Madrid: Centro de Estudios Políticos y Constitucionales, 2007, pp. 103-107. 
guerra de la Independencia y de la Revolución que de la propia Constitución: "el futuro Estado liberal de hecho finalmente se construyó al margen por completo de la Constitución de 1812".11

Una de las resoluciones más transcendentes de la naciente constitución fue la declaración de la libertad de imprenta. El hecho de que fuera aprobada por las Cortes antes que la propia Constitución sirvió para garantizar la libertad del proceso constitucional y fue una pieza esencial para el funcionamiento del sistema liberal. Su reconocimiento significó la posibilidad de difundir libremente ideas, pensamientos, sentimientos e informaciones sin necesidad de pasar por el filtro de los censores; por ello constituyó un medio muy efectivo para ilustrar a la población. Los poderes públicos solo podían exigir responsabilidades después de la publicación de los escritos. Sin embargo, como consecuencia de la concesión que tuvieron que realizar los diputados liberales, quedaron excluidos los documentos que versaran sobre cuestiones religiosas ${ }^{12}$.

En Reus, la promulgación de la Constitución se solemnizó el 26 de septiembre. La celebración religiosa tuvo un destacado papel. Durante el oficio de la misa, en el ofertorio, se leyó el texto en voz alta y el sacerdote pronunció un laudatorio. A continuación los vecinos hicieron el juramento, se entonó un Te Deum, voltearon las campanas y se dispararon cargas de artillería. El día anterior, Sebastián Torroja, regidor decano del Ayuntamiento, dispuso en un bando cómo debería desarrollarse el festejo. Entre otros requerimientos, solicitó a la ciudadanía la ornamentación de las calles por donde debía de transitar la comitiva:

...demà dissabte a les quatre horas de la tarda se tinguian bien limpios, dessembossats y adornats tots els carrers y se posian colgaduras en todas las casas del curs que fan les profesons de Corpus y de san Pere per ahont se ha determinat pasia lo Ajuntament, la tropa y acompañament de la Constitució...

Las fiestas, con presencia de las comparsas de gigantes y el bestiario, incluyendo una exhibición de fuegos artificiales, se prolongaron durante tres días. ${ }^{13}$

11. MORENO ALONSO, M. La Constitución de Cádiz. Una mirada crítica. Sevilla: Ediciones Alfar, 2011, pp. 38-53, 64 y 67.

12. FERNÁNDEZ SEGADO, F. "La libertad de imprenta en las cortes de Cádiz". Revista de Estudios Políticos (Nueva Época). Núm. 124 (2004). Abril-junio, pp. 29-54; el mismo autor en "El camino hacia el reconocimiento de la libertad política de la imprenta por las Cortes de Cádiz". Revista de las Cortes Generales, Núm. 86, 2012, pp. 7-156. MAGADALENO ALEGRIA, A. "El origen de la libertad de imprenta en España". En MIRANDA RUBIO, F. (coord.). Guerra, Sociedad y Política (1808-1814). Vol. II. Pamplona: Universidad Pública de Navarra, pp. 10071026. MAGDALENO ALEGRIA, A. "La libertad de imprenta como premisa de la primera constitución racional-normativa española: la constitución de Cádiz de 1812". Revista de Derecho Político. Núm. 87 (2013), pp. 223-252.

13. ANGUERA NOLLA, P. Comportament polític $i$ actituds ideològiques al Baix Camp: 1808-1868. Reus: Associació d'Estudis Reusencs, 1983, p. 27. También en Arxiu Comarcal del Baix Camp (ACBC). Fons Municipal de Reus. Actes municipals 1811-1812, fol. 348-361. 


\section{La prensa en el contexto de la época}

Los orígenes de la prensa en Europa se remontan al siglo XVI con la aparición en Alemania de calendarios, almanaques y hojas impresas ocasionales. Los textos se referían a noticias de política internacional, relatos de enfrentamientos bélicos, de descubrimientos, de sucesos religiosos. En 1588 Michael von Eyzinger editaba en Colonia Postrema relatio historica, una publicación semestral escrita en latín, destinada al lector culto. Esta prensa, con la aparición de las primeras gacetas, se va a consolidar durante el siglo XVII. En 1631, gracias el apoyo de Richelieu, Théophraste Renaudot sacó en Francia la Gazette: tenía periodicidad semanal y publicaba noticias del extranjero (diplomáticas y militares), de la Corte (nacimientos, bodas, fallecimientos) y de París. En Italia las primeras gacetas aparecieron en Florencia (1636) y en Génova (1639). ${ }^{14}$

En la Monarquía Hispánica, durante los últimos años del siglo XV y a lo largo del $\mathrm{XVI}$, se publicaron crónicas y relaciones con unos contenidos diversos, entre los que sobresalieron las descripciones de acontecimientos políticos o militares. Sevilla y Barcelona fueron los centros más activos en cuanto a la difusión de este tipo de impresos. En el siglo XVII Madrid se sumó al afán informativo y se convirtió en el centro donde desarrollaron su actividad los más importantes relacioneros; centraban la atención noticias referidas a la corte, asuntos domésticos, corridas de toros y sucesos sociales. Dentro del contexto de crisis de mediados de siglo aparecieron las gacetas, cuya culminación llegó con la edición en 1661 de la Gazeta de Madrid. A imitación de la madrileña también hubo gacetas provinciales en otras ciudades como Sevilla, Zaragoza o Valencia. Minoritaria todavía en el siglo XVIII, la difusión generalizada de la prensa no se producirá hasta llegar al siglo XIX, viviendo, en función de los acontecimientos políticos, alternativamente épocas de expansión y de hermetismo. Pese a los límites de su alcance, para los Borbones españoles la prensa significó en el setecientos un instrumento de control político, un elemento de proyección de la cultura y un signo de progreso ${ }^{15}$.

14. PIZARROSO QUINTERO, A. "La prensa en España y en Europa a caballo entre dos siglos: panorama comparado". En MORALES MOYA, A. (coord.). 1802. España entre dos siglos, Sociedad y Cultura. Madrid: Sociedad Estatal de Conmemoraciones Culturales, 2003, pp. 295-320. También PIZARROSO QUINTERO, A. (coord.). Historia de la prensa. Madrid: Centro de Estudios Ramón Areces, 1994. Esta publicación incluye los artículos del mismo Pizarroso, "Evolución histórica del periodismo en Italia"; de Ingrid Schulze, "La prensa en Alemania"; y de María Antonia Paz Rebollo, "El periodismo en Francia", cuyos contenidos se corresponden con las páginas 56,108 y 146 respectivamente. NAVARRO MIRALLES, L. "La prensa europea en la Edad Moderna, unas anotaciones". En FÀBREGAS ROIG, J.; NAVAIS ICART, J. (coords.). Premsa i societat. Aspectes polítics econòmics i socials. Reus: Arola Editors, Publicacions URV, Centre de Lectura, 2013, pp. 41-73.

15. SAIZ GARCIA, M. Dolores. Historia del Periodismo en España. Los orígenes. El siglo XVIII. Madrid: Alianza, 1995, pp. 32, 34, 42, 60 y 87. 
Más que los libros, reservados a un grupo restringido de lectores, la prensa española fue un elemento decisivo para la difusión cultural del Siglo de las Luces. El desarrollo de la prensa periódica estuvo vinculado al avance de la alfabetización y al de la educación en general. Fue el principal medio para la difusión de las noticias, para la creación de la opinión pública, para vehicular los grandes debates de la llustración y para propiciar el cambio social. Sus contenidos abarcaban temas muy variados, incluía información erudita o literaria, temática religiosa y crítica de costumbres, de medicina, de pedagogía y de economía. Materias que se difundieron gracias a diversos tipos de periódicos: los diarios, que se caracterizaron por su elitismo, su afrancesamiento y su interés pedagógico; las gacetas, más populares y orientadas hacia la información; y los almanaques y pronósticos. ${ }^{16}$

Fue en la segunda mitad del siglo XVIII, en plena Ilustración, cuando la prensa periódica alcanzó relevancia, gracias a la conjunción de una serie de factores: lectores interesados, financiación suficiente, editores emprendedores y mejoras técnicas. Eran publicaciones independientes, algunas poco gratas al poder, que en determinadas circunstancias se vieron acosadas por la censura. La invasión francesa, el comienzo de la guerra de la Independencia y la exaltación del espíritu patriótico las revolucionó, surgiendo así nuevas iniciativas, sobre todo publicaciones de tema político.

Las primeras referencias de publicaciones periódicas, además de las oficiales Gazeta de Madrid (1661) y Mercurio histórico y político $(1738)^{17}$, fueron el Diario de los literatos de España y las Efemérides barométrico-médicas, ambas aparecidas en 1737. Con posterioridad surgieron el Diario Noticioso (1758), El Pensador (1761), El Censor (1781) o El espíritu de los mejores diarios de Europa (1787). El Diario de los literatos de España, que se situaba a la altura de los mejores diarios de Europa, se dedicó a la crítica literaria e inauguró la etapa de esplendor de la prensa. En 1758 Francisco Mariano Nipho fundó el primer diario nacional, el llamado Diario Noticioso, Erudito y Comercial, Público y Económico; una publicación del tipo misceláneo en cuyas páginas pretendía conciliar artículos de opinión con noticias de carácter comercial. El Pensador (1761-1767), periódico moderado, editado por José Clavijo Fajardo, presentaba un contenido orientado a la crítica social dentro de una línea claramente ilustrada. ${ }^{18}$ María Dolores Sáiz afirma que Clavijo participa plenamente del pensamiento ilustrado: pretende recuperar las virtudes del pasado, se duele de la decadencia del presente y desarrolla una verdadera campaña contra la ignorancia, la superstición, la falsa virtud, los prejuicios y la intolerancia. ${ }^{19}$ En el período final del siglo, El espíritu de

16. MARTínEZ SHAW, C. El Siglo de las Luces. Las bases intelectuales del reformismo, Madrid: Temas de Hoy, 1996, p.94.

17. ENCISO RECIO, L. M. La Gaceta de Madrid y el Mercurio histórico y político, 17561781. Valladolid, 1957.

18. MARTÍNEZ SHAW, C. "La prensa y la difusión de las Luces en la España del siglo XVIII". En FÀBREGAS ROIG, J.; NAVAIS ICART, J. (coords.) Premsa i societat..., pp. 15-37.

19. SAIZ GARCÍA, M. D. Historia del periodismo..., p. 159. 
los mejores diarios de Europa ofrecía información de los avances que se producían en el ámbito del conocimiento en este continente, indistintamente que fuera científico o humanístico. Considerado como el gran periódico de la llustración, merece una mención especial El Censor, de Luís García del Cañuelo, un periódico que desde sus páginas pretendía la regeneración de la sociedad de su tiempo, a través de una implacable crítica social que lo situaba en un marco ideológico prácticamente liberal. Según Carlos Martínez Shaw, si tenemos en cuenta la frecuencia con que trató los temas eclesiásticos, se le puede considerar el portavoz del sector jansenista del clero español ${ }^{20}$.

En 1786 se publicó El Correo de los ciegos. Con el dinero de su venta se intentaba aliviar la difícil situación económica que atravesaban los invidentes desde mediados de siglo, cuando los diarios dejaron de venderse por las calles y sólo se podían adquirir en las librerías.

En general, con algunas excepciones, la mayor parte de la prensa del XVIII se caracterizó por la difusión de ideas económicas, avances científicos y descubrimientos técnicos, temas de debate en la Europa ilustrada. Sin embargo, también se caracterizó por una gran fragilidad, que se exteriorizó en su escaso número, su limitada tirada y su corta duración. ${ }^{21}$

Desde el momento en que en Francia se inició el proceso revolucionario, Floridablanca se sintió alarmado por los acontecimientos que se sucedían e intentó silenciar las noticias provenientes de dicho país. Las informaciones que desde 1787 aparecieron en la Gazeta de Madrid o en el Mercurio de España no eran de temática política y tampoco el resto de periódicos estaban autorizados a difundir este tipo de contenido. El ministro pronto se dio cuenta que acallar la prensa oficial no era suficiente pues numerosas publicaciones francesas llegaron a España en el verano de 1789. Para impedirlo, el 18 de septiembre y el 1 de octubre se publicaron sendas reales órdenes con instrucciones para que los oficiales de las aduanas y puertos marítimos confiscaran aquellos documentos que aludieran a los sucesos que se producían al otro lado de la frontera. Igualmente, por estas mismas fechas, Floridablanca acudió a la Inquisición para que colaborara en las tareas de censura. En enero y agosto de 1790 se prohibió la importación, la impresión y la propagación de cualquier producto que hiciera referencia a la revolución que se vivía en Francia, no importaba que fueran libros, estampas, cajas, abanicos o tejidos. A mediados de septiembre de 1791 la Gazeta de Madrid reproducía una real orden que insistía en la que había publicado en enero del año anterior. ${ }^{22}$

20. MARTÍNEZ SHAW, C. El Siglo de las Luces..., p. 68.

21. MARTíNEZ SHAW, C. El Siglo de las Luces..., p. 94. También en "La prensa y la difusión de las luces...", pp. 15-37.

22. HERR, Richard. España y la revolución del siglo XVIII. Madrid: Aguilar, 1973, pp. 197219. 
Finalmente el 24 de febrero de 1791, a consecuencia del movimiento revolucionario francés, quedaron suspendidas las publicaciones periódicas con la excepción de la Gazeta, ${ }^{23}$ el Mercurio y el Diario de Madrid. Algunos diarios, como el Diario de Barcelona, lograron esquivar la prohibición al dedicarse a difundir noticias de teatro y de espectáculos públicos, del movimiento de embarcaciones comerciales y de curiosidades científicas, así como anuncios. El mencionado periódico, hasta la guerra de la Independencia, en que fue confiscado por el mariscal Joachim Murat, no incluyó ni noticias políticas ni mercantiles. ${ }^{24}$

La guerra de la Independencia, en los territorios no ocupados, favoreció el nacimiento de numerosos diarios, muchos de ellos de tendencia liberal, que en general tuvieron un corto recorrido. Según Josep Francesc Valls, el periodismo de este período condensaba toda la actividad intelectual: artículos inflamatorios contra los franceses, canciones o poesías patrióticas. Los escritores se dejaron llevar por la oleada de acción política que la guerra imponía. Como en épocas similares, cesó radicalmente la actividad literaria y científica y los escritores y ensayistas se dedicaron a escribir en los periódicos. Eran diarios poco elaborados, de escaso recorrido, redactados en papel de calidad ínfima, en comparación con la prensa inglesa del momento. Como contenido, figuraban referencias a las sesiones de les Cortes; noticias de la guerra, tanto de la Península como del exterior; ataques a diarios rivales y comentarios tediosos. El mismo propietario, a veces con la ayuda de algún familiar, redactaba el texto e incluso lo distribuía por medio de la entrega de parte de la edición a pedigüeños y a mujeres, que lo repartían por las calles; otra parte se distribuía entre los suscriptores..$^{25}$

Manuel Gómez Imaz, en su clásico estudio, situaba a Cádiz, con cincuenta y seis cabeceras, como la ciudad líder en publicaciones entre 1808 y 1814 , aunque probablemente no fuesen más de diez al mismo tiempo. La mitad de la prensa gaditana se podía considerar de ideología liberal. Muy cerca, en la Isla de León, cuna de la Constitución, había cinco, tres de ellas dentro de la órbita progresista. Madrid y Sevilla sumarían treinta y seis; pero mientras que en la capital la mitad eran de tendencia liberal, en Sevilla tenían tintes más diversos, con publicación de diarios patrióticos, conservadores y liberales moderados. Esa misma tendencia se puede apreciar en Palma de Mallorca y Valencia. En Palma, de veinticuatro publicaciones, la mitad eran conservadoras y una cuarta parte

23. En el artículo de DUFOUR, G. "La Gazeta afrancesada de Madrid (1808-1813)". Cuadernos de Ilustración y Romanticismo. Revista Digital del Grupo de Estudios del Siglo XVIII. Universidad de Cádiz. Núm.16 (2010), pp. 1-41. <http://revistas.uca.es/index.php/cir/article/ view/187> [Fecha de consulta: 26/01/2014], podemos apreciar la evolución de este periódico oficial durante el período de la ocupación francesa.

24. VALLS, J. F. Prensa y burguesía en el siglo XIX español. Barcelona: Anthropos, 1988, p. 53.

25. VALLS, J. F, Prensa y burguesía..., pp. 61-66. 
liberales; en Valencia, de dieciocho, la mitad se catalogaban como patriotas, cinco se posicionaban como absolutistas y sólo una, El Redactor General, tenía carácter netamente liberal. ${ }^{26}$

Por su carácter progresista destacaron los diarios que a continuación se refieren. Así, en $\mathrm{Cádiz}^{27}$, donde surgió con más empuje la prensa liberal, los más exaltados eran: El Clarín de la libertad, El Conciso ${ }^{28}$, El Duende de los Cafés y El Mentor ó Ilustrador Popular. Más moderados fueron La Abeja española, El Tribuno del Pueblo Español, El Amante de la libertad civil, El Amigo de las damas, La Barbería, La Campana del lugar, El Centinela de la Constitución Española, La Década, El Duende político ${ }^{29}$, El Imparcial, El Liberal, El Observador, El Patriota en las Cortes, El Redactor generaß ${ }^{\beta 0}$, El Semanario Patriótico ${ }^{31}$ y La Tertulia Patriótica $^{32}$. En la Isla de León, El Robespierre español, amigo de las leyes, El

26. GOMEZ IMAZ, M. Los periódicos durante la guerra de la Independencia (1808-1814). Madrid, 1910. Otra panorámica de la prensa más reciente, la tenemos en la publicación de GIL NOVALES, A. Prensa, guerra y revolución. Los periódicos españoles durante la Guerra de la Independencia. Madrid: CSIC-Ediciones Doce Calles, 2009.

27. Con relación a la prensa gaditana resulta imprescindible la consulta de CANTOS, M.; DURÁN, F.; ROMERO, A. (eds.). La Guerra de Pluma. Estudios sobre la prensa de Cádiz en el tiempo de las Cortes. 3 Vols. Cádiz: Universidad de Cádiz, 2006.

28. MARTíN SÁNCHEZ, I. "El Conciso un periódico liberal en tiempos de las Cortes de Cádiz". Trienio: Ilustración y liberalismo. Núm. 30, (1997), pp. 23-46. DURÁN LÓPEZ, F. "Prensa y Parlamentarismo en Cádiz en el primer año de las Cortes: El Conciso (septiembre de 1810-agosto de 1811)". El Argonauta español. Núm. 4 (2007), pp. 2-21. <http://argonauta. revues.org/1296> [Fecha de consulta: 26/01/2014]

29. Ver también HERNÁNDEZ GONZÁLEZ, M. "Entre Europa y América. El periodismo de Cabral de Noroña. Del Duende político gaditano al Observador español en Londres". Cuadernos de Ilustración y Romanticismo. Revista Digital del Grupo de Estudios del Siglo XVIII. Universidad de Cádiz. Núm.16 (2010), pp. 1-24. <http://revistas.uca.es/index.php/cir/article/ viewArticle/192> [Fecha de consulta: 26/01/2014].

30. SÁNCHEZ HITA, B. "El Redactor General (1811-1814) de Pedro José Daza o cómo hacer un gran periódico en el Cádiz de las Cortes". Cuadernos de Ilustración y Romanticismo. Revista Digital Grupo de Estudios del Siglo XVIII. Universidad de Cádiz. Núm.16 (2010), pp. 1-49. <http://revistas.uca.es/index.php/cir/article/view/176> [Fecha de consulta: 26/01/2014].

31. Manuel Gómez Imaz indica tres etapas para este periódico: la primera se desarrolla en Madrid en 1808, en el momento de su fundación; la segunda corresponde a su traslado a Sevilla, comprendiendo desde finales de 1808 hasta agosto de 1809; y la tercera, la etapa gaditana, va desde 1810 hasta 1812.

32. ANGULO EGEA, M. "Un hueco para otro periódico político en el Cádiz de las Cortes: La Tertulia Patriótica (octubre 1810-febrero 1811)". Cuadernos de Ilustración y Romanticismo. Revista Digital del Grupo de Estudios del Siglo XVIII. Universidad de Cádiz. Núm.16 (2010), pp. 1-16. <http://revistas.uca.es/index.php/cir/article/viewArticle/182> [Fecha de consulta: $26 / 01 / 2014]$

GIL NOVALES, A. "El periódico Tertulia patriótica de Cádiz". Trienio. Núm. 34 (noviembre 1999), pp. 81-100. 
Telescopio político y La Triple Alianza ${ }^{33}$. En Madrid: El Semanario Patriótico ${ }^{34}$, La Abeja madrileña, El Amigo de las leyes, El Ciudadano imparcial, El Patriota ${ }^{35}$ y El Redactor General de España, radical. En Palma de Mallorca, La Antorcha ${ }^{36}$, La Aurora Patriótica Mallorquina y El Diario político y mercantil de Palma, los tres de ideas avanzadas ${ }^{37}$. En Sevilla, A Sevilla libre y El Diario Redactor, y en Valencia, el Redactor general. ${ }^{38}$

Contrariamente, entre los diarios absolutistas despuntaron los siguientes: En Cádiz, El Censor general de Cádiz, El Diario patriótico de Cádiz, El Diario de la tarde, Diarrea de las Imprentas, El Procurador General de la Nación y del Rey ${ }^{39}$ y El Sol de Cádiz; en Madrid, La Atalaya de la Mancha en Madrid y El Censor general, continuación del diario gaditano; en Sevilla, El Correo político y mercantil de Sevilla, El Diario patriótico de Sevilla, Juan Verdades y La Píldora; en Palma de Mallorca, El Amigo de la verdad, Diari de Buja, Diario Balear, Gazeta triunfo mensual, Lluna patriótica mallorquina, Nuevo diario de Palma, Semanario cristiano político de Mallorca, y en Valencia, El Criticón de Valencia, Lucindo, El

33. Con relación a El Conciso, La Década, El Duende político, El Observador, El Redactor general, El Robespierre español, El Semanario Patriótico y La Tertulia Patriótica ver: DURÁN LÓPEZ, F. "Diputados de papel: la información parlamentaria en la prensa de la etapa constituyente (septiembre 1810-marzo 1812)". En CANTOS, M.; DURÁN, F.; ROMERO, A. (eds.). La Guerra de Pluma..., Vol.2, pp. 37-282.

34. Fue fundado por el intelectual Manuel José Quintana. Con respecto a su etapa madrileña ver el estudio de RICO LINAGE, R. "Revolución y opinión pública: el Semanario Patriótico en 1808". Historia, instituciones, documentos. Núm. 25 (1998), pp. 577-604. MORENO ALONSO, M. "El Semanario Patriótico y los orígenes del liberalismo en España". Anuario del Departamento de Historia. Facultad de Ciencias de la Información, Madrid, (1991), pp. 167-182. Con relación al fundador ver QUINTANA, M. J. de. Memoria sobre el proceso y prisión de D. Manuel José Quintana en 1814. Alicante: Biblioteca virtual Miguel de Cervantes, 1999. <http://www.cervantesvirtual.com/obra/memoria-sobre-el-proceso-y-prision-de-donmanuel-jose-quintana-en-1814--0/> [Fecha de consulta: 26/01/2014].

35. GIL NOVAlES, A. "El Patriota de José Mor de Fuentes". Spagna Contemporanea. Núms. 8 y 9 (1995 y 1996), pp. 7-18 y 45-78.

36. GIL NOVALES, A. "La Antorcha, Palma 1813". El Argonauta español Núm.5, (2008), pp. 1-18. <http://argonauta.revues.org/984> [Fecha de consulta: 26/01/2014].

37. ROURA I AULINAS, LI. L'Antic Règim a Mallorca: abast de la commoció dels anys 1808-1814. Palma: Conselleria d'Educació i Cultura, 1985, pp. 263-286 y 362-369.

38. Manuel Gómez Imaz, ordenado en su publicación con el número 277, lo califica como de liberal avanzado y sitúa su edición hacia 1813. También añade que fue incluido en el edicto de la Inquisición de 22 de julio de 1815.

LAGUNA PLATERO, A. "La prensa liberal valenciana (1808-1840)". En RAMÍREZ ALEDÓN, G. (ed.). El primer liberalisme: L'aportació valenciana. Valencia: Biblioteca Valenciana, 2001, pp. 72-88.

39. RODRÍGUEZ GUTIÉRREZ, M. "Las modalidades literarias en la prensa de las Cortes de Cádiz: El Caso de El Procurador General de la Nación y del Rey (1812-1813)". En CANTOS, M.; DURÁN, F.; ROMERO, A. (ed.) La Guerra de Pluma..., Vol. 1, pp. 305-389. Periódico antirreformista orientado a ilustrar los valores de la nación, del rey y vigilante de los valores tradicionales del absolutismo. 
Observador político y militar de España ${ }^{40}$ y El Periódico momentáneo de Valencia el Fernandino.

Un comentario diferenciado merece El Español, diario liberal publicado en Londres por José María Blanco White, eclesiástico, colaborador de Isidoro de Antillón en el Semanario Patriótico, cuando se editaba en Sevilla. Desde El Español, diario político y literario, fue muy crítico contra la Constitución y contra las Cortes, a las que acusaba de aglutinar excesivo poder y, como alternativa, proponía el modelo monárquico inglés. También fue crítico con la gestión que las autoridades españolas hacían de las colonias, en un momento en que se extendían los primeros movimientos independentistas. ${ }^{41}$

En Cataluña, Jaume Guillamet, para los años de la guerra, tiene catalogados hasta treinta y siete diarios, de los cuales treinta eran españoles y siete franceses, aparte de cinco más por documentar: El Noticiero, El Patriota y El Noticioso, todos de Manresa; la Gazeta de Tortosa y la Gazeta Extraordinaria Provincial de Cataluña, de Tarragona. ${ }^{42}$ Manuel Gómez Imaz catalogó el Diario del Imperio Francés, afrancesado, editado en Vic y reimpreso en Reus. ${ }^{43}$ Esos diarios representaban aproximadamente el diez por ciento de la prensa española de aquellos años. La presencia de las tropas napoleónicas y la guerra, en Cataluña, condicionaron el desarrollo de la prensa, la libertad de imprenta y, obviamente, la propia revolución liberal. Al igual que en el resto de España, en Cataluña había aparecido la Gaceta de la Regencia como diario oficial -la Gazeta de Madrid estaba bajo control francés- y vio también la luz la Gazeta Militar y política del Principado de Cataluña que siguió el itinerario de la Junta Superior y se publicó en varias poblaciones. Ambos periódicos, junto con el Diario de Barcelona ${ }^{44}$, afrancesado, abarcaron todo el período de la guerra. En cuanto a Manresa ${ }^{45}$, Vic y Tarragona, que en algún momento del conflicto fueron sede de la Junta, destacaron en número de publicaciones; si bien hay que

40. LEÓN NAVARRO, V. "El Observador Político y Militar de España. Un periódico para la regeneración". Cuadernos de Ilustración y Romanticismo. Revista Digital del Grupo de Estudios del Siglo XVIII. Universidad de Cádiz. Núm. 16 (2010), pp. 1-23. <http://revistas.uca.es/ index.php/cir/article/view/193/186> [Fecha de consulta: 26/01/2014].

41. VARELA SUANZES-CARPEGNA, J. "Un precursor de la monarquía parlamentaria: Blanco-White y 'El Español' (1810-1814)". Revista de Estudios Políticos (Nueva Época). Núm. 79 (enero-marzo 1993), p.107.

42. GUILLAMET LLOVERAS, J. Els orígens de la premsa a Catalunya. Catàleg de periòdics antics (1641-1833). Barcelona: Arxiu Municipal de Barcelona, 2003. pp. 94 y 96.

43. GÓMEZ IMAZ, M. Los periódicos..., p. 108.

VILASECA ANGUERA, S. Informació sanitària sobre el port de Salou. Reus: Associació d'Estudis Reusencs, 1976, p. 67.

44. COMAS GÜELL, M. "Antoni Brusi Mirabent (1775-1821). De artesano a industrial". Jerónimo Zurita Revista de historia. Núm. 83 (2008), pp. 85-108.

GIL NOVALES, A. "El Diario de Barcelona en 1808". En Josep Fontana. Història i projecte social. Reconeixement a una trajectòria. Vol II. Barcelona: Crítica, 2004, pp. 1059-1078.

45. VILA-MASANA PORTABELLA, J. "La premsa a Manresa durant el període 1808-1814". Dovella. Núm. 104 (2010), pp. 16-27. 
hacer constar que las principales poblaciones no ocupadas, como réplica al Diario de Barcelona, hicieron difusión de su propia prensa. ${ }^{46}$ (Véase cuadro I).

La ocupación francesa tuvo una especial incidencia en el desarrollo del periodismo en Cataluña. Mientras estuvo vigente, su contenido se centró en noticias relativas al desarrollo de la guerra. El hecho de que las grandes ciudades catalanas estuviesen bajo control galo convirtió la Gazeta militar y política del Principado de Cataluña en un referente, entre 1808 y 1814. Si valoramos la ideología y el contenido de aquellos diarios, con añadido de los afrancesados, podemos observar un predominio de los de carácter patriótico y de los que publicaban noticias sobre el conflicto. Según cuál fuese su inspiración ideológica, reproducían extractos procedentes de publicaciones de otras ciudades donde el tema político preferente eran los acuerdos constitucionales. Con frecuencia, aquella prensa se convirtió en campo de batalla dialéctico. Fue el caso de la polémica que protagonizaron en otoño de 1808 el Diario de Manresa y el Diario de Barcelona. A raíz de la declaración del estado de sitio, que publicó el Diario de Barcelona el 17 de setiembre, por orden del general Guillaume Philibert Duhesme, el Diario de Manresa se refirió a los hechos como la "gran Duhesmada (o sea Satanasada o infernada)". El general francés a través del diario barcelonés, con frecuencia, respondía personalmente a las diatribas de los periódicos de algunas localidades de Cataluña, en especial a las del manresano, el más mentiroso de todos, según palabras de Duhesme. Con frecuencia, el Diario de Manresa reproducía noticias de su rival afrancesado de Barcelona, para que sus lectores pudieran apreciar como desfiguraba la realidad. ${ }^{47}$

El decreto de libertad de imprenta de noviembre de 1810, ratificado dos años después por la Constitución, en Cataluña tuvo una repercusión limitada. Solamente a partir de la retirada de las tropas napoleónicas hubo un cierto pluralismo político y periodístico. Los periódicos ya no dependían solo de las Juntas locales, sino que algunos podían interesar a editores privados. Tres se pueden calificar de liberales (el Redactor General de Cataluña, de Vic; el Periódico político y mercantil de la Villa de Reus y el Eco de Reus) y dos de ideología servil (El Patriota Ausonense y Centinela de la Patria en Reus). ${ }^{48}$

46. GUILLAMET LLOVERAS, J. Els orígens de la premsa a Catalunya..., pp. 89-99. Ver también el dossier sobre la prensa histórica en Cataluña en Plecs d'Història Local, núm. 147 en L'Avenç. Núm. 384. Noviembre, (2012) y en él, FÀBREGAS ROIG, J. "La premsa històrica digitalitzada ara" L'Avenç. Núm. 384. Plecs d'Història Local (noviembre 2012), pp. 11 y 12.

47. GUILLAMET LLOVERAS, J. Els orígens de la premsa a Catalunya..., pp. 113 y 114.

48. Ibídem. pp. 143 y 248. 
LOS ORÍGENES DE LA PRENSA LIBERAL: EL CASO DEL PERIÓDICO POLÍTICO Y MERCANTIL...

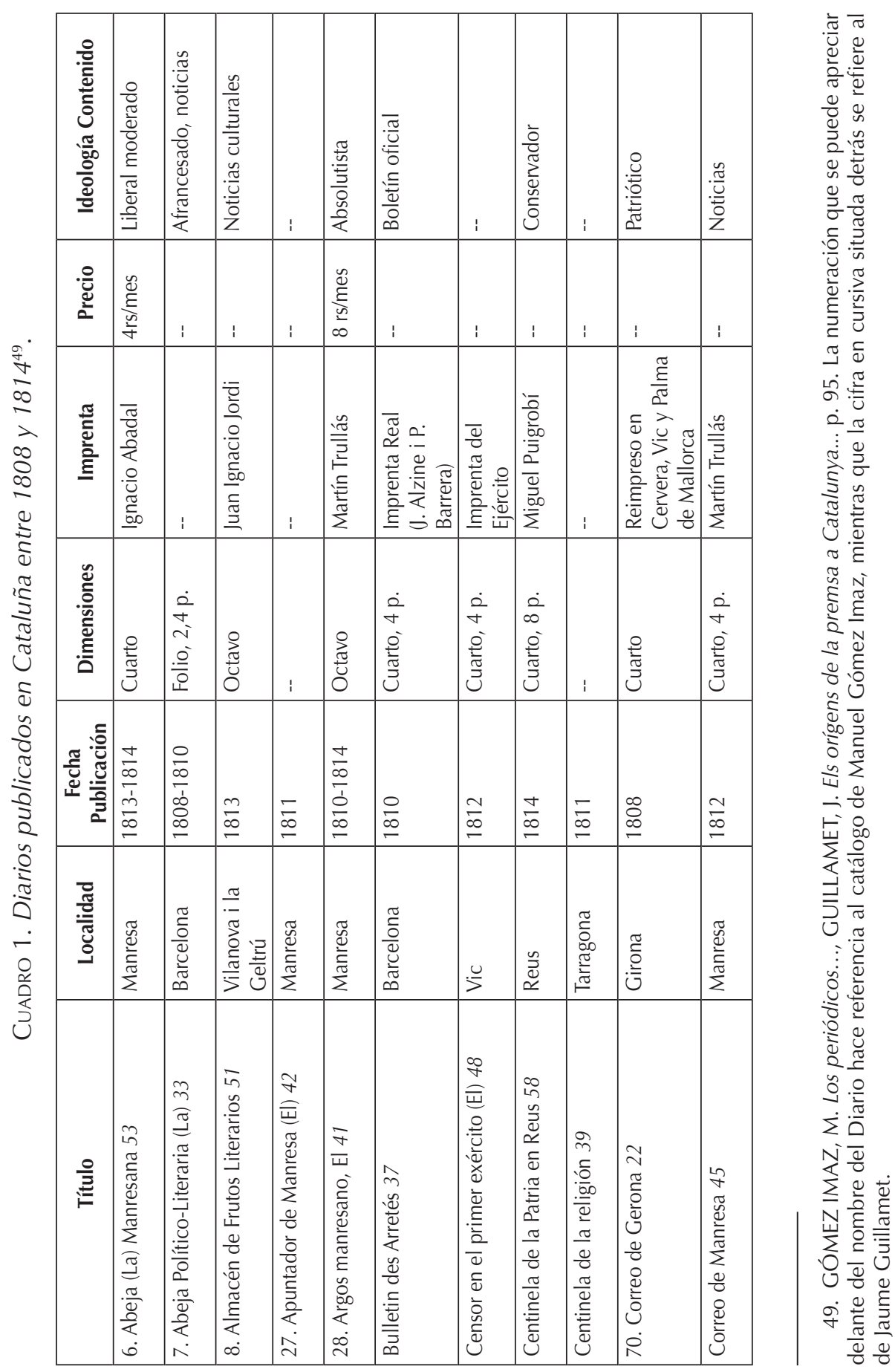


JOSEP FÀBREGAS ROIG

\begin{tabular}{|c|c|c|c|c|c|c|c|c|c|c|c|c|c|}
\hline 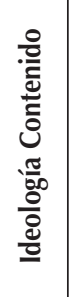 & : & 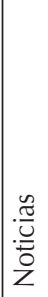 & 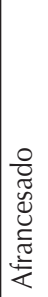 & 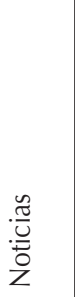 & 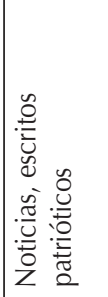 & 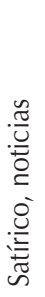 & 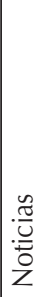 & $\begin{array}{l}\frac{\pi}{0} \\
: \frac{0}{0} \\
\frac{0}{Z}\end{array}$ & $\frac{\pi}{\frac{\pi}{\pi}}$ & 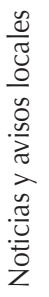 & $\mid \frac{\pi}{\frac{\pi}{U}}$ & 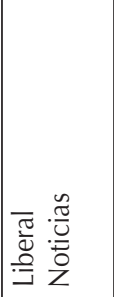 & 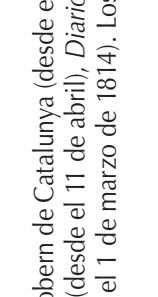 \\
\hline . & $i$ & 1 & \begin{tabular}{|l}
$\frac{n}{2}$ \\
$\frac{\tilde{m}}{20}$ \\
$\infty$
\end{tabular} & $\frac{\tilde{E}}{\frac{w}{2}}$ & $i$ & 1 & ! & $i$ & 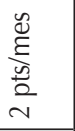 & 1 & 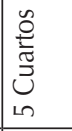 & 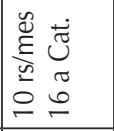 & 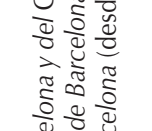 \\
\hline 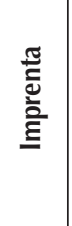 & 1 & 1 & 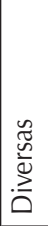 & 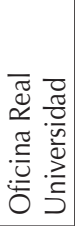 & 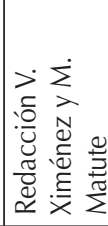 & 1 & 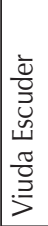 & 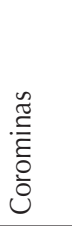 & 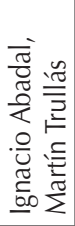 & 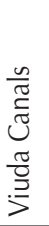 & 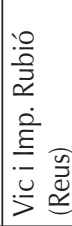 & 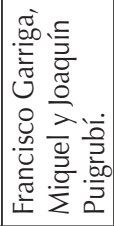 & 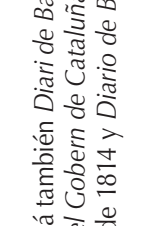 \\
\hline 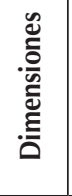 & 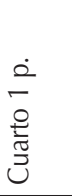 & $\begin{array}{l}\dot{2} \\
\dot{a} \\
\dot{0} \\
\dot{0} \\
\frac{1}{3}\end{array}$ & $\begin{array}{l}\dot{2} \\
\infty \\
+ \\
0 \\
0 \\
\dot{0} \\
\frac{1}{3} \\
0\end{array}$ & $\begin{array}{l}\dot{0} \\
\infty \\
0 \\
0 \\
0 \\
\frac{0}{0} \\
\frac{0}{3}\end{array}$ & 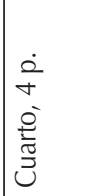 & $\begin{array}{l}\dot{2} \\
\dot{0} \\
\dot{0} \\
\dot{0} \\
\text { J̃ }\end{array}$ & $\begin{array}{l}\dot{2} \\
\dot{2} \\
\dot{0} \\
\dot{0} \\
\frac{1}{3}\end{array}$ & i & 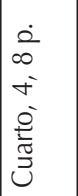 & $\begin{array}{l}\dot{2} \\
\dot{y} \\
\dot{0} \\
\dot{0} \\
\text { Jँ }\end{array}$ & $\begin{array}{l}\dot{2} \\
\infty \\
0 \\
0 \\
\frac{1}{2} \\
3 \\
0\end{array}$ & $\begin{array}{l}\dot{2} \\
\dot{y} \\
\dot{0} \\
\dot{0} \\
\stackrel{0}{3}\end{array}$ & 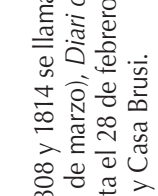 \\
\hline 胥 & $\begin{array}{l}\infty \\
\stackrel{\infty}{\circ}\end{array}$ & $\frac{N}{\infty}$ & 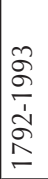 & $\mid \begin{array}{l}0 \\
\infty \\
0 \\
01 \\
0 \\
0 \\
-\end{array}$ & $\mid \begin{array}{l}0 \\
0 \\
\infty \\
1 \\
\infty \\
0 \\
0 \\
-1\end{array}$ & $\begin{array}{l}\infty \\
\stackrel{\infty}{\infty} \\
\infty\end{array}$ & $\begin{array}{l}0 \\
\infty \\
+\infty \\
\infty \\
0 \\
\infty \\
-1\end{array}$ & $\begin{array}{l}\infty \\
\stackrel{\infty}{0} \\
\infty\end{array}$ & $\begin{array}{l}0 \\
\infty \\
0 \\
01 \\
0 \\
0 \\
0\end{array}$ & 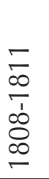 & $\frac{m}{\infty}$ & $\begin{array}{l}\frac{\pi}{ \pm} \\
\frac{\infty}{\vdots} \\
\frac{1}{\infty} \\
\infty\end{array}$ & 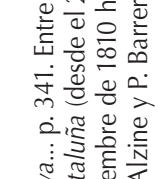 \\
\hline 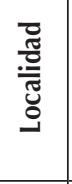 & 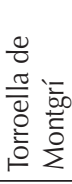 & 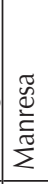 & 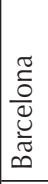 & 咅 & 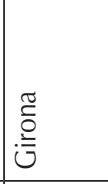 & $\begin{array}{l}\frac{\pi}{\frac{\pi}{\pi}} \\
\frac{\pi}{\pi} \\
\underline{\underline{\sigma}} \\
\underline{0}\end{array}$ & $\frac{\pi}{0}$ & $\frac{\pi}{\frac{\pi}{0}}$ & 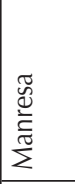 & 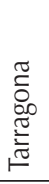 & $\stackrel{u}{>}$ & 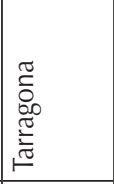 & 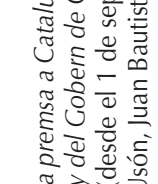 \\
\hline 旁 & 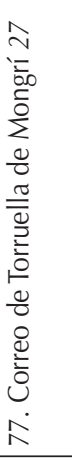 & 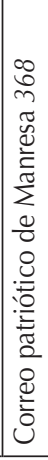 & 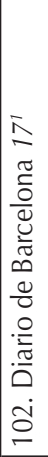 & 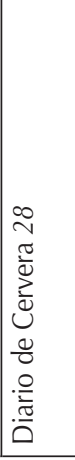 & 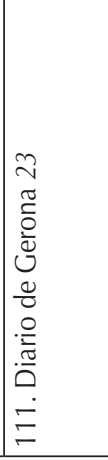 & 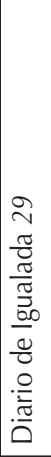 & 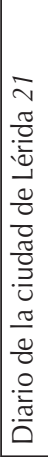 & 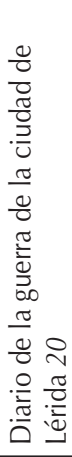 & 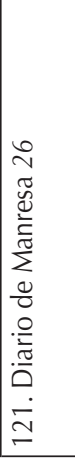 & 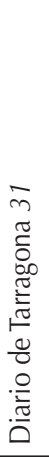 & 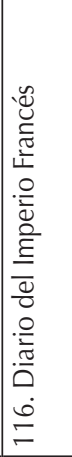 & 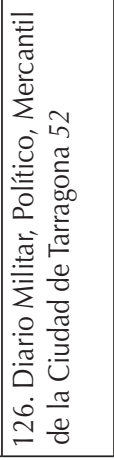 & 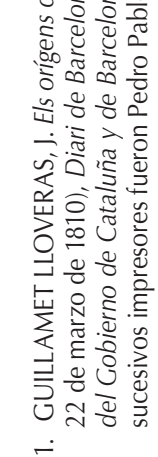 \\
\hline
\end{tabular}




\begin{tabular}{|c|c|c|c|c|c|c|c|c|c|c|c|}
\hline 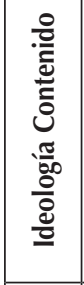 & 莺 & 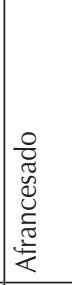 & 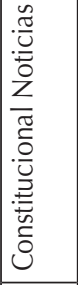 & 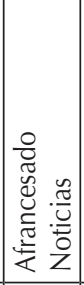 & 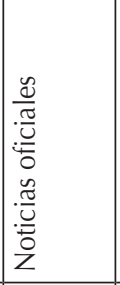 & 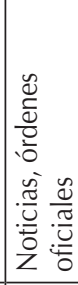 & 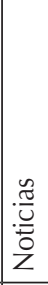 & 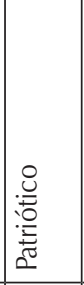 & 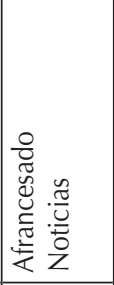 & $\begin{array}{l}\frac{\pi}{0} \\
\frac{\pi}{0} \\
Z \\
Z\end{array}$ & $i$ \\
\hline 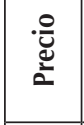 & $\mathrm{i}$ & 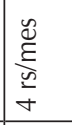 & 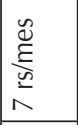 & $i$ & $\mathrm{i}$ & की & 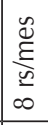 & $i$ & क्ञ & i & $\mathrm{i}$ \\
\hline $\begin{array}{l}\text { 플 } \\
\text { 흘 }\end{array}$ & 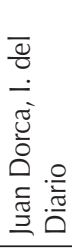 & 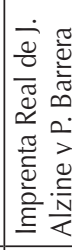 & 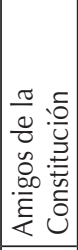 & 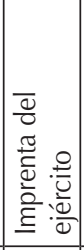 & 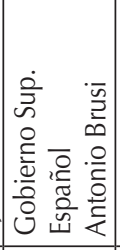 & 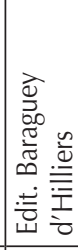 & 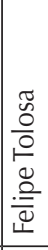 & 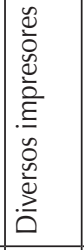 & 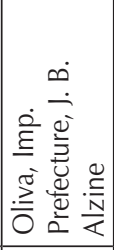 & 1 & 1 \\
\hline 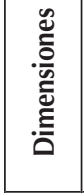 & $\begin{array}{l}\dot{0} \\
\infty \\
\dot{0} \\
\dot{0} \\
\dot{0} \\
\frac{0}{3}\end{array}$ & $\begin{array}{l}\dot{2} \\
\dot{+} \\
\dot{\gamma}\end{array}$ & $i$ & 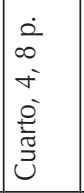 & $\begin{array}{l}0 \\
\infty \\
0 \\
.0 \\
\frac{0}{0}\end{array}$ & $\begin{array}{l}\dot{2} \\
+ \\
\dot{0} \\
\frac{0}{0}\end{array}$ & $\begin{array}{l}0 \\
\infty \\
0 \\
0 \\
0 \\
0 \\
0 \\
3\end{array}$ & 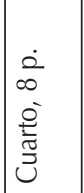 & $\begin{array}{l}\frac{\dot{2}}{+} \\
.0 \\
\frac{0}{0}\end{array}$ & $\frac{ㅇ}{0}$ & 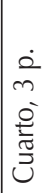 \\
\hline 胥 & $\begin{array}{l}\bar{\sigma} \\
\frac{1}{5} \\
\frac{1}{\infty} \\
0\end{array}$ & \begin{tabular}{l}
0 \\
$\infty$ \\
0 \\
1 \\
8 \\
$\infty$ \\
\hdashline \\
\end{tabular} & $\frac{\Delta}{\infty}$ & $\frac{0}{\infty}$ & 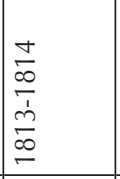 & $\underset{\infty}{\infty}$ & $\begin{array}{l}0 \\
\infty \\
\infty \\
\infty \\
0 \\
\infty \\
\infty \\
- \\
\end{array}$ & $\begin{array}{l}m \\
\infty \\
\overline{0} \\
\infty \\
0 \\
\infty \\
-0 \\
-1\end{array}$ & 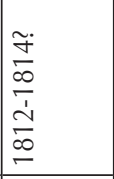 & $\begin{array}{l}\infty \\
\infty \\
\infty\end{array}$ & $\frac{N}{\infty}$ \\
\hline 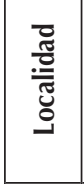 & $\stackrel{u}{\prime}$ & 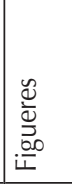 & $\mid \begin{array}{c}\tilde{z} \\
\stackrel{a}{\alpha}\end{array}$ & 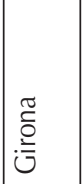 & 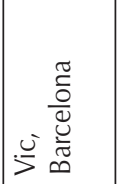 & 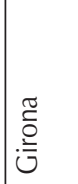 & $\stackrel{0}{>}$ & 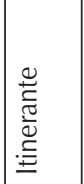 & 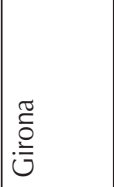 & 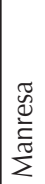 & 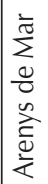 \\
\hline 呈 & 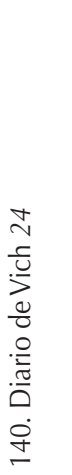 & 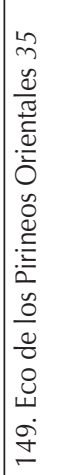 & 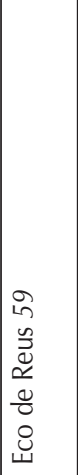 & 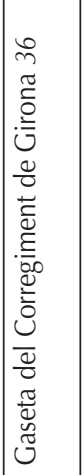 & 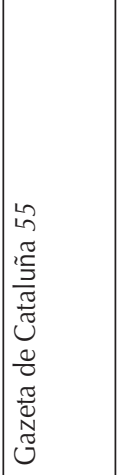 & 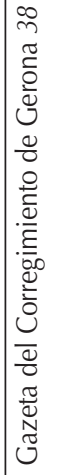 & 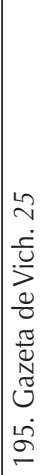 & 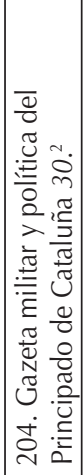 & 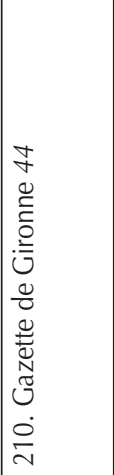 & 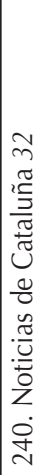 & 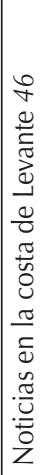 \\
\hline
\end{tabular}

心

总完文造

可

휴

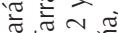

잉

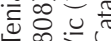

$\dot{0}=\frac{10}{2}$

象

प्र

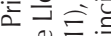

$\overline{0} \div \frac{0}{\infty}$

흔 큰 웡

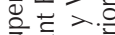

号芯

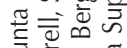

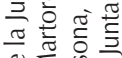

낭 $\frac{n}{0} \pi$

$\sqrt{0.0}$

渮㐫

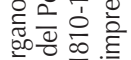

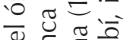

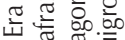

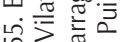

㘳

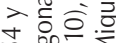

古

은?

政

空全说,

정

羟

ช

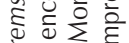

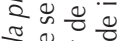

용 중뭉

응 응.은

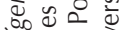

흐웡ㅎㅇ

네응 은

ज立离

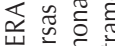

ว

궁ㅇㅇ

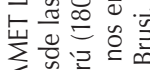

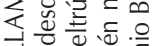

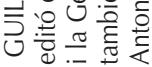

ن 
JOSEP FÀBREGAS ROIG

\begin{tabular}{|c|c|c|c|c|c|c|}
\hline 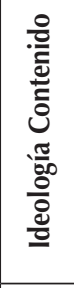 & 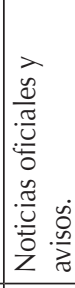 & 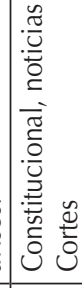 & 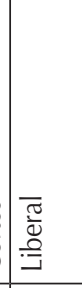 & 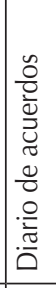 & 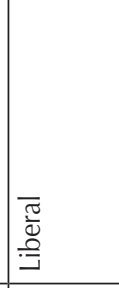 & 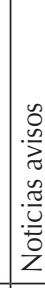 \\
\hline 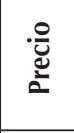 & 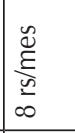 & 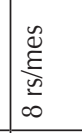 & 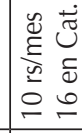 & : & 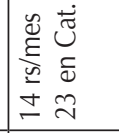 & 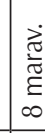 \\
\hline 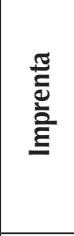 & 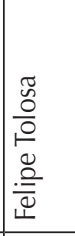 & 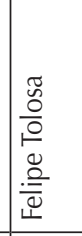 & 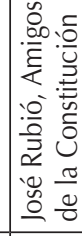 & 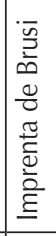 & 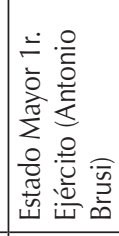 & 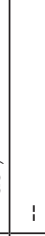 \\
\hline 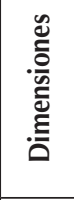 & 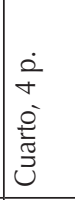 & 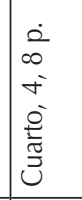 & 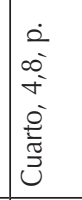 & 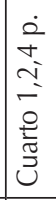 & 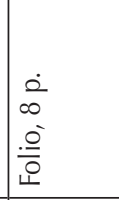 & $\begin{array}{l}\dot{a} \\
\infty \\
\dot{\gamma}\end{array}$ \\
\hline 胥 & $\frac{-1}{\frac{1}{\infty}}$ & 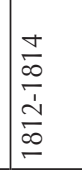 & \begin{tabular}{|l}
$\frac{\sigma}{\infty}$ \\
$\frac{\infty}{\bar{n}}$ \\
$\frac{\omega}{\infty}$ \\
-
\end{tabular} & $\frac{\stackrel{0}{\infty}}{=}$ & $\underset{\infty}{\frac{\pi}{\infty}}$ & $\begin{array}{l}\stackrel{8}{\infty} \\
\sim\end{array}$ \\
\hline 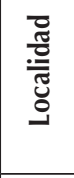 & $\stackrel{u}{>}$ & $\stackrel{u}{5}$ & 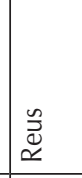 & 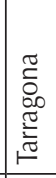 & $\stackrel{u}{>}$ & 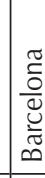 \\
\hline 告 & 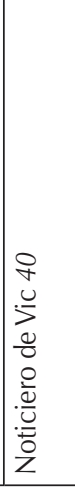 & 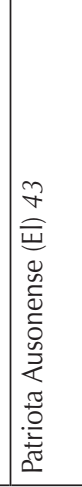 & 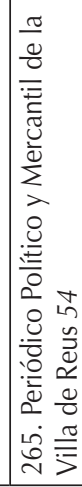 & 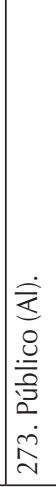 & 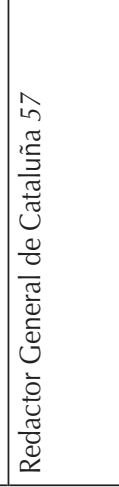 & 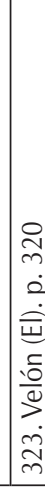 \\
\hline
\end{tabular}




\section{La prensa liberal en Reus}

Si nos centramos en la prensa local, puede servirnos de ayuda la realidad de Reus. La referencia de las ideas liberales la encontramos en dos diarios: Periódico político y mercantil de la Villa de Reus y Eco de Reus. ${ }^{50}$ Por su parte, la oposición estaría representada por una tercera publicación: Centinela de la Patria en Reus. ${ }^{51}$ Editado en esta ciudad, aunque impreso en Tarragona, fue un instrumento de propaganda al servicio de Fernando VII cuya significación, como afirma Xavier Ferré, cabe buscar en el hecho de que se editó durante el regreso del monarca del exilio. ${ }^{52}$ Gómez Imaz y Gil Novales citan también el Periódico extraordinario de Reus, una de las muchas publicaciones realizadas por los Cuerpos de Ejército. Consistía en una hoja en folio impresa por una cara en la oficina de José Rubió. Si Gómez Imaz, en 1910, sólo había localizado los ejemplares correspondientes al 5 y al 13 de octubre de 1813, por nuestra parte hemos encontrado también el del 14 de noviembre. ${ }^{53}$

El Periódico político y mercantil de la Villa de Reus publicó el primer ejemplar el 4 de octubre de 1813, mientras que el Eco vería la luz el 16 de abril de 1814 y el Centinela se daría a conocer el primero de abril de aquel mismo año, coincidiendo con la entrada triunfal de Fernando VII en Reus. ${ }^{54}$ El Periódico se identificó con la ideología liberal y, como su nombre indica, su contenido atendió a los aspectos políticos y económicos. Su editor fue el médico Jaume Ardévol. ${ }^{55}$ Seguía el formato de octavo

50. El Periódico político y mercantil de la Villa de Reus, el Eco de Reus y el Centinela de la patria en Reus se encuentran depositados en la Biblioteca Central Xavier Amorós de Reus.

ANGUERA NOLLA, P. Comportament polític..., pp. 31-39. Aporta una descripción de estas publicaciones. GUILLAMET LLOVERAS, J. Els orígens de la premsa a Catalunya..., p. 120. FÀBREGAS ROIG, J. "La difusió de les idees liberals a la premsa d'inici del segle XIX". En FABREGAS ROIG, J.; NAVAIS ICART, J. (coords.). Premsa i societat, pp. 77-94.

51. GÓMEZ IMAZ, M. Los periódicos..., pp. 27 y 72. En 1810 Antonio de Capmany había editado en Cádiz, entre junio y agosto, un periódico con el mismo título, aunque con ideología bien diferente.

52. FERRÉ TRILL, X. El ECo de Reus (1814) y El Centinela de la patria en Reus (1814). Reedición facsímil. Reus: Associació d'Estudis Reusencs, 1997, p. XII. Para el conjunto de la prensa reusense, GIL NOVALES, A. Prensa, guerra..., pp. 64, 108 y 168; GÓMEZ IMAZ, M. Los periódicos..., pp. 233 y 234; y GUILLAMET LLOVERAS, J. Els orígens de la premsa a Catalunya..., pp. 120-122. AGUADÉ BRUIX, E. Bibliografía reusenca fins al 1900, Reus: Associació d'Estudies Reusencs, 1998.

53. GÓMEZ IMAZ, M. Los periódicos..., p. 232 y GIL NOVALES, A. Prensa, guerra..., p. 167. Consultado el 06/01/2012 véase también http://www.todocolección.net/.

54. Con relación a los tres periódicos disponemos del artículo de María Dolores Gimeno Puyol, "Entre la paz y las polémicas: Fernando el Deseado en la prensa reusense 1813-1814". Annals de l'Institut d'Estudis Gironins. Vol. LI (2010), pp. 259-277.

55. Jaume Ardèvol (1773-1835) había nacido en Vilella Alta, municipio de la provincia de Tarragona, en la comarca del Priorat. Cursó estudios en las Universidades de Huesca y Cervera, y se doctoró en medicina en la de Montpellier. Participó en la Guerra Gran (1793-1795) como capitán de la sexta compañía de miqueletes del Tercio de Tarragona y como médico en la de la Independencia. Ejerció la medicina en Reus, gozando de un enorme prestigio, fue miembro de la Academia de Medicina y Cirugía de Barcelona. Persona de grandes inquietudes, mostró su preocupación por diversos aspectos del ámbito de la ciencia, de la cultura, de 
mayor, y tenía entre cuatro y ocho páginas. Se empezó a imprimir en la oficina de José Rubió, en el colegio de San Juan, hasta que el primero de enero de 1814 se trasladó a la calle de Monterols. A comienzos de febrero le encontramos en la calle de Jesús y terminó su andadura en la imprenta de los Amigos de la Constitución, en la calle dels Recs, a cargo de Joaquín Artigas.

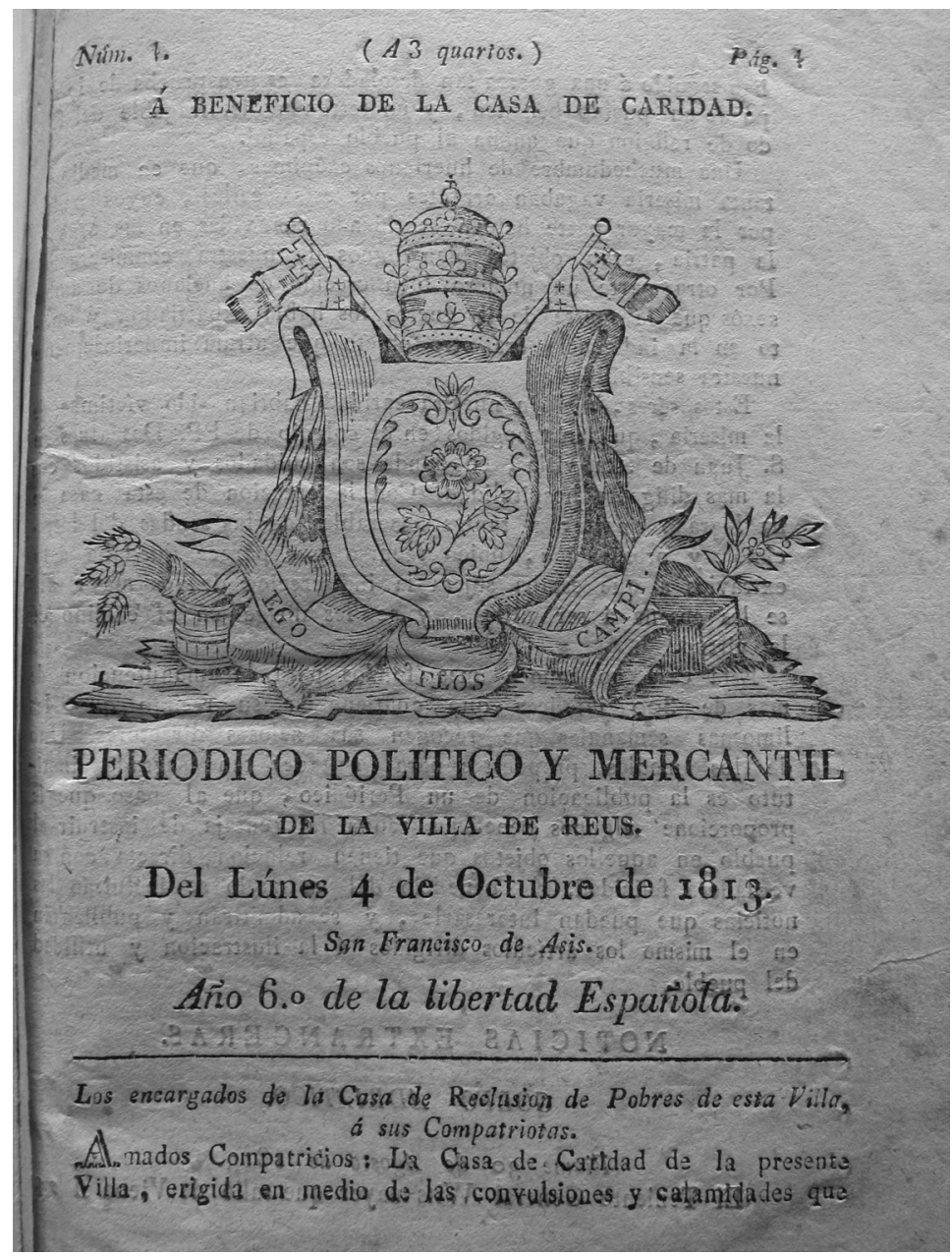

la sociedad y de la política. Una de sus interesantes aportaciones fue la Memoria acerca de la Fiebre Amarilla observada en Gibraltar en el año 1828, publicada en 1846, en Barcelona, en la imprenta de la viuda Espona. Véase en Salvador Vilaseca Anguera, asimismo médico, historiador y arqueólogo que le biografió en Informació sanitària..., pp. 59-90. También en ELÍAS DE MOLINS, A. Diccionario biográfico y bibliográfico de escritores y artistas catalanes del siglo XIX. Tomo 1. Barcelona, 1889, pp. 109-115. 
En la cabecera del Periódico político y mercantil de la Villa de Reus, debajo del precio, inicialmente de tres "quartos", se podía leer: "Á beneficio de la casa de la caridad". ${ }^{56}$ En el primer número, presidiendo la portada, se estampó el escudo de Reus ${ }^{57}$. A continuación venía el título, la fecha, el santoral del día y la frase: "Año $6^{\circ}$ de la libertad Española". El artículo de presentación, cuyo título era "Los encargados de la Casa de Reclusión de Pobres de esta Villa, á sus compatriotas", justificaba los objetivos del diario, entre los cuales, además de la presentación de artículos y anuncios de interés, estaba el altruista. Recordemos que una de las consecuencias que padeció Reus a raíz de la guerra de la Independencia fue el empobrecimiento de la población, lo que afectó fundamentalmente a huérfanos, mujeres y ancianos. Como el convento de los frailes Carmelitas Descalzos de San Juan estaba desocupado, por encontrarse los frailes exiliados en Francia, el Ayuntamiento permitió que se convirtiera en centro de acogida para los necesitados, unos trescientos. Su manutención se costeaba en buena parte con los ingresos generados por la publicación. ${ }^{58}$

El contenido del Periódico no se diferenciaba en demasía del de otros homólogos contemporáneos. En él tenían cabida las noticias extranjeras: desde Lisboa, Londres, Viena y otras capitales europeas se relataba lo que acaecía con respecto a las tropas napoleónicas. Venían después los sucesos del "Reyno" con referencias al desarrollo de la fase final de la guerra de la Independencia y a las reuniones de las Cortes, con la inclusión de los decretos aprobados. Al lado figuraban los hechos acaecidos en Cataluña, vinculados también, en buena parte, al conflicto bélico. En la última hoja solían publicarse las "Noticias particulares de Reus", acompañadas de informaciones de carácter económico, como podían ser las entradas y salidas de embarcaciones de los puertos de Salou y de Tarragona o los listados de precios que, en el mercado de la ciudad, registraban las distintas variedades de aguardiente y los productos de procedencia colonial. Con cierta frecuencia, aparecían notas de avisos sobre objetos extraviados, peticiones de servicios y anuncios sobre venta o alquiler de inmuebles.

La parte cultural del Periódico se concretaba en poemas (sonetos, décimas y coplas), concebidos -con mayor o menor fortuna- en homenaje a diputados ilustres o a la Libertad, así como en el aviso de la aparición de publicaciones, fuese la Constitución de Cádiz o las Colecciones de decretos promulgados por

56. La cuota mensual era de 10 reales para los subscriptores de Reus, de 16 para los del Principado y de 20 para los del resto de la monarquía. Los gastos de envío estaban incluidos.

57. Se puede observar la tiara y las llaves de su patrón San Pedro, en el centro una rosa, símbolo de la ciudad, y en la parte inferior unas espigas y una rama de olivo, distintivos de su actividad económica.

58. Periódico político y mercantil de la Villa de Reus. Núm. 1. Lunes 4 de octubre de 1813. Oficina de Rubió. pp. 1 y 2. Núm. 47. Viernes 19 de diciembre de 1813, pp. 191-197. Una función similar tenían el Diario de Manresa y el Diario del Imperio Francés. Jaume Guillamet en Els orígens de la premsa a Catalunya..., p. 113 manifiesta que la edición del diario manresano dependía de la Junta de Caridad y que los beneficios que producía servían para pagar las 3.400 raciones de sopa que se repartían cada día a los necesitados. 
las Cortes. Se insertaban también las novedades literarias que se podían adquirir en Reus, como las obras del padre Feijoo, piezas clásicas (Trabajos de Persiles y Segismunda de Miguel de Cervantes), pedagógicas (El nuevo Robinson, historia moral reducida á diálogos para instrucción y entretenimiento de niños y jóvenes de ámbos sexos de Joachim Heinrich Campe) o de contenido económico (Guide des Négocians de Laurent Lipp). También tenían cabida los anuncios de las representaciones teatrales que realizaba la Sociedad Dramática (La mujer de dos maridos, María Teresa de Austria, El galeote cautivo, Fernando VII en Bayona...).

Aunque a comienzos del siglo XIX Reus era una ciudad importante, la segunda de Cataluña en cuanto a número de habitantes, el carácter universalista del Periódico exigía que parte de las noticias procediesen de otras fuentes. De ahí que en sus páginas hallaran eco artículos difundidos en la prensa más significada de la nación: La Aurora Patriótica Mallorquina, El Conciso (Cádiz), Diario de Alicante, Diario de Zaragoza, Diario Provincial de Valencia, Duende de los Cafés (Cádiz), Gazeta de La Coruña, Gazeta de Madrid, Gazeta del Principado [de Cataluña] (Itinerante), Gazeta Provincial de Valencia, Gazeta de Valencia, Redactor General de Cádiz, Redactor General de Cataluña (Vic), Redactor General de España (Madrid), Telégrafo portugués (Sevilla), Tribuno del pueblo español (Cádiz) y El Universal (Madrid).

En honor a su título, la parte más sustanciosa del Periódico de Reus estaba relacionada con los acontecimientos que suscitaba la actividad política. El diario, de hecho, nació bajo la bandera de la libertad y fue un ejemplo de pluralismo ideológico. Incluso se dio el caso de que, en el número 14, un lector, por nombre Desiderio Félix, se mostró contrariado al ver frustradas sus esperanzas de que el periódico denunciase a quienes vulneraban la Constitución. He aquí sus argumentos:

Al considerar el contraste de la libertad y del despotismo me he dicho muchas veces á mi mismo: ¿Quién sabe si la Constitución no será para estos tiempos ó si acaso no se hizo para nosotros? Yo no veo más que infracciones, y ningún infractor castigado, y quando se nos llama ciudadanos y libres, es quando estamos más lejos de la libertad. Que, ¿acaso los catalanes no somos españoles? ¿No hemos hecho bastantes sacrificios á favor de la causa pública, para que dexemos de gozar de las prerrogativas que nos concede la ley? ${ }^{59}$

Cuando el Periódico vio la luz, el 4 de octubre de 1813, como ya quedó dicho, las Cortes generales y constituyentes habían cerrado ya las sesiones (14/9/1813). Y, a pesar de que pudiese parecer que poco quedaba ya por hacer, la labor de divulgación del nuevo credo realizada por el diario fue amplia en cantidad y exigente en calidad. A pesar de ello, el historiador Andreu de Bofarull apuntó

59. Periódico político y mercantil. Núm. 14. Domingo 17 de octubre de 1813, pp. 54-56. 
que los reusenses lo recibieron con una cierta indiferencia, y solo un reducido número de lectores se interesaron en leer los airados párrafos que se vertían en sus páginas ${ }^{60}$. Fue precisamente la finalización de las sesiones en septiembre de 1813 una de les primeras noticias publicadas con respecto a las Cortes:

Sesión del dia 14. Leida el acta del dia anterior, se leyó enseguida el siguiente decreto: Acercándose el dia en que los Diputados de las Córtes ordinarias deben reunirse para el exámen de sus respectivos poderes, las Córtes generales y extraordinarias han decretado cerrar sus sesiones hoy 14 de setiembre de 1813. Lo tendrá entendido la Regencia del Reyno \&c. ${ }^{61}$.

En el número 12, se publicó la elección del presidente, vicepresidente y secretarios de las Cortes, sobre quienes pesaba la responsabilidad de dirigir la asamblea ordinaria. El cargo de presidente recayó en Francisco Rodríguez de Ledesma, diputado por Extremadura; para vicepresidente fue elegido Gonzalo Herrera, representante de la Isla de Cuba; Ramon Feliu, delegado del Perú, fue designado primer secretario; en cuanto a la segunda secretaría, destacó la presencia del representante de Guipúzcoa Miguel Antonio de Zumalacárregui, hermano del conocido general carlista; la tercera fue ocupada por Pedro Alcántara de Acosta, comisionado también por Cuba, y la cuarta por Antonio Díaz, diputado por Granada. El lunes 25 de octubre, se informó del discurso pronunciado por José Canga Argüelles ${ }^{62}$ en la sesión del día 3, referido a la organización del Ejército. Canga Argüelles destacaba la necesidad de dotarlo de una organización acorde a los nuevos tiempos, opinaba que el número de efectivos que lo integraban tenía que estar en relación con los recursos disponibles e insistía en que el hecho de formar parte de la milicia no fuera impedimento para que el soldado pudiera disfrutar de

60. BOFARULL I BROCÁ, A. Anales históricos de Reus, desde su fundación hasta nuestros días. Vol. II. Reus: Imprenta de Pedro Sabater, 1846, p. 155.

61. Periódico político y mercantil. Núm. 5. Viernes 8 de octubre. La noticia procedía de la Gazeta de Valencia, núm. 24.

62. MENÉNDEZ Y PELAYO, M. Biblioteca de traductores españoles. Edición de Enrique Sánchez Reyes. Biblioteca Virtual Miguel de Cervantes, 2008. Edición nacional de las obras completas de Marcelino Menéndez Pelayo. Vol. 54. Santander: CSIC, 1952-1953. <http:// www.cervantesvirtual.com/obra/biblioteca-de-traductores-espanoles-abenatarcortes--0> [Fecha de consulta: 27/01/2014]. José Canga Argüelles y Cifuentes nació en Oviedo, en 1791 se doctoró en Cánones y Leyes por la Universidad de Zaragoza. Fue poeta, traductor, político y autor de tratados de economía. Miembro de diversas Sociedades Económicas de Amigos del País. Como político se asoció a la causa liberal; en 1804 fue nombrado Contador General del Ejército en Valencia, en esta ciudad le sorprendió el movimiento revolucionario y fue vocal de la Junta Suprema. En 1811 fue designado Secretario interino de Estado y del Despacho Universal de Hacienda; dos años después fue elegido diputado por Asturias y durante el gobierno de la Regencia ocupó la cartera de Hacienda. Con la restauración del absolutismo fue sentenciado a ocho años de prisión en el castillo de Peñíscola. Restablecida la constitución en 1820 fue nuevamente diputado a cortes y Ministro de Hacienda. Con el retorno del absolutismo emigró a Londres, regresando a España en 1833. 
los derechos que le correspondían como ciudadano civil. Para dar cumplimiento a sus argumentos reclamaba la creación de una comisión de Constitución militar, que estaría asesorada por los Secretarios del Despacho de la Guerra, del de Hacienda y del de Gobernación e incluso por personas de probada capacidad ajenas al Congreso. ${ }^{63}$ Los redactores de la noticia se hicieron eco de las razones esgrimidas por el diputado asturiano:

...sean nuestros militares Ciudadanos en los batallones, sean Ciudadanos delante del enemigo, sean Ciudadanos en los quarteles... y quede el nombre de soldado, reservado para los que obedezcan á tiranos. Hagamos, Señor, Ciudadanos á los militares y demos á los exércitos el carácter de Ciudad... ${ }^{64}$.

En números sucesivos, el Periódico se refirió también a los acuerdos que se alcanzaban en Cádiz. En sus páginas podemos encontrar artículos relacionados con las reformas de los conventos o la supresión de la Inquisición. Mención aparte merece la atención prodigada al atentado del que fue objeto la noche del 3 de noviembre de 1813 el diputado aragonés Isidoro de Antillón, al abandonar el edificio de las Cortes. Como el resto de la prensa liberal, el Periódico lo reflejó no sólo como un ataque personal, sino como un ultraje a las instituciones ${ }^{65}$. Al día siguiente Antillón dirigió el siguiente parte a la cámara:

Al retirarme anoche de la sesión extraordinaria, en la misma boca de la calle del Vestuario, donde habito, me acometieron tres asesinos, de los cuales uno descargó sobre mi cabeza un golpe, al parecer de sable, tan furioso y terrible que me arrojó tendido en tierra a algunos pies de distancia...Por fortuna, la manera con que venía cubierto y el sombrero hicieron que el golpe no haya producido los resultados que el asesino creyó asegurar. Sigo en la cama, y aunque débil y desconcertado, sin riesgo ni calentura. ${ }^{66}$

63. Actas de las sesiones de la Legislatura ordinaria de 1813: dieron principio el $1^{\circ}$ de Octubre de 1813 y terminaron el 19 de Febrero de 1814. Madrid: Imprenta y fundición de la Viuda e Hijos de Juan Antonio García, 1876. Sesión del día 3 de octubre del año 1813, pp. 50 y 51.

64. Periódico político y mercantil. Núm. 22. Lunes 25 de octubre de 1813, pp. 89-92. Noticia procedente de El Tribuno del pueblo Español, núm. 27.

65. CAPEL, H. "Isidoro de Antillón (1778-1814)". Boletín Informativo. Fundación Juan March. Núm. 166 (enero 1987), pp. 3-18. Antillón, intelectual ilustrado, se formó en Derecho pero terminaría siendo catedrático de geografía. Tomó posesión de su escaño el 23 de mayo de 1813. Antes, el 1809, había llegado a Sevilla donde, con José María Blanco White, dirigió el Semanario Patriótico, fundado por Manuel Quintana. Fue también director del Archivo de Indias y de la Gaceta del Gobierno. La Junta Suprema, entonces ubicada en Cádiz, le nombró magistrado de la Audiencia de Mallorca, lugar que ocupó en junio de 1810. En 1812 fundó el periódico Aurora Patriótica Mallorquina. El Periódico se hacía eco de la noticia del atentado en los números 51 y 52.

66. Actas de las sesiones de la Legislatura ordinaria de 1813: dieron principio el $1^{\circ}$ de Octubre de 1813 y terminaron el 19 de Febrero de 1814. Madrid: Vda. e Hijos de J. Antonio García, 1876. Sesión del 4 de noviembre de 1813, p. 198. 
El 21 de diciembre unos amigos suyos, en la iglesia de San Jaime de la ciudad de Palma, solemnizaron una acción de gracias a la Virgen del Pilar por haber preservado la vida del diputado turolense. ${ }^{67}$

También tenemos noticia en el Periódico de la evolución de la fiebre amarilla, que en otoño de 1813 afectó nuevamente a Cádiz y provocó el traslado de los congresistas a Madrid. La Junta Suprema de Sanidad determinó una cuarentena de quince días para las embarcaciones procedentes de dicha ciudad y de ocho de ventilación para los productos que transportaran. Con los episodios de 1800, 1804, 1811 y 1813, en una situación que se podría denominar de endémica, la ciudad gaditana, como otras poblaciones andaluzas, se vio afectada por la fiebre amarilla. Después de una tregua -entre 1808 y 1809- en que había permanecido con "buena salud", a pesar que se registraban un promedio de siete fallecimientos diarios, en 1810 y 1813 la fiebre reapareció. El hecho que la localidad andaluza fuera uno de los últimos baluartes que había podido evitar la ocupación francesa, contribuyó a que la densidad de población aumentara considerablemente y con ella el riesgo de contagio. ${ }^{68}$

Y en cuanto a los decretos relacionados con la iglesia, motivo de intenso debate en el hemiciclo y entre la opinión pública, el Periódico se hizo eco de cuantos dieron lugar a la reforma de los conventos y a la incorporación de los religiosos al ejército ${ }^{69}$. La cuestión de la supresión de la Inquisición fue un tema muy controvertido. Así, los números 35 y 36 publicaron el artículo La Inquisición confundida, crónica que refería la representación leída en las Cortes el 17 de agosto, en la que el agustino fray Andrés del Corral, Catedrático de Sagrada Escritura en la universidad de Valladolid, apuntó varias causas que había incoado el citado tribunal. Concretamente, las dirimidas durante el siglo XVI contra fray Luis de León, catedrático en Salamanca; Gaspar de Grajal, amigo de fray Luis, abad de Santiago de Peñalba y catedrático en dicha Universidad; Martín Martínez Cantalapiedra, profesor de hebreo también en Salamanca; fray Alonso Gudiel, agustino, catedrático de Biblia en Osma, y Francisco Sánchez de las Brozas, catedrático de retórica y lengua griega, asimismo en la universidad salmantina. El delito por el cual los inquisidores acusaban a los cuatro primeros era afirmar que la Vulgata en muchas cosas se podía mejorar. Mientras que a Sánchez le acusaron sus discípulos por haber dicho que las once mil Vírgenes no habían sido en tan excesivo número, y que quien decía mal de Erasmo, era frayle o era asno.

67. Acción de gracias que en la solemnísima fiesta... dijo D. Manuel Rullán, presbítero. Palma: Imprenta de Miguel Domingo, 1813.

68. Periódico político y mercantil. Núm. 38. Miércoles 10 de noviembre de 1813, pp. 154 y 155.

MELLADO, B. Historia de la epidemia..., pp. 5-7. FIGUERA VON WICHMANN, E. de la. "Las enfermedades más frecuentes a principios del siglo XIX y sus tratamientos". En TORRES AURET, M. L. (coord.). Los Sitios de Zaragoza..., pp.151-171.

69. Periódico político y mercantil. Núm. 30. Martes 2 de noviembre de 1813. pp. 122-124. Núm. 46. Jueves 18 de noviembre de 1813, pp. 187-189. 
Andrés del Corral había obtenido la citada documentación a raíz del incendio que se había producido en 1809 en las casas de la Inquisición de Valladolid ${ }^{70}$; posteriormente había recopilado estos procesos en cinco volúmenes, pero por no disponer de medios económicos no los había podido publicar y los ofreció al Congreso ${ }^{71}$. A la supresión de este tribunal también se refirió Agustín Íñigo Abbad y Lasierra, obispo de Barbastro, en otra exposición realizada ante las Cortes:

La Inquisición, Señor, hablemos con el verdadero lenguaje de los Patriotas católicos; la Inquisición, tribunal obscuro y cercado de tan densas tinieblas, era incompatible con las instituciones francas de V. M... Doy, pues, las más reverentes gracias á Dios como autor principal de todos nuestros bienes, y à V.M. por la sabiduría y resolución magnánima con que ha roto las ataduras que tan injustamente oprimían nuestras manos, restituyendo a los obispos unas facultades que les son nativas, y derrocado sobre dicho tribunal de la Inquisición; monumento de oprobio tan ominoso a la política como a la religión. ${ }^{72}$

A mediados de diciembre de 1813 el Congreso y el Gobierno estaban preparando el traslado a Madrid. En Cádiz, el 26 de noviembre, se había editado una proclama redactada por Un español, dedicada "Al heroico pueblo de Madrid", que el Periódico reimprimió. En ella, este patriota exhortaba a los madrileños a perseverar en la defensa de las libertades alcanzadas durante los últimos tiempos y, como si fueran ingenuos, les advertía de estar vigilantes para no sucumbir a falsas quimeras:

...Tales son madrileños, los sentimientos de un hermano vuestro, que admirando vuestro valor y constancia, y deseando que cojáis el fruto de vuestro sacrificios quiere daros estos saludables avisos para que viváis precavidos contra los traidores, los enemigos de las luces, los amigos del despotismo, y los protectores de los antiguos desórdenes, á fin de que

70. FERNÁNDEZ MARTíN, L. "La casa de la Inquisición de Valladolid". Investigaciones Históricas. Núm. 10 (1990), pp.189-202. El incendio sucedió en la madrugada del 7 de setiembre de 1809 cuando servían de cuartel de soldados alemanes y franceses; como había orden de no tocar las campanas durante la noche no se dieron cuenta de que el fuego se había expandido tanto que tardaron cuatro días en apagarlo. Del edificio se conservó la fachada quedando el resto prácticamente destruido.

71. Periódico político y mercantil. Núms. 35 y 36. Domingo 7 y lunes 8 de noviembre de 1813, pp. 142, 143 y 145-148. Reimpreso del número 100 de La Aurora Patriótica Mallorquina. Biblioteca Virtual de Prensa Histórica. La Aurora Patriótica Mallorquina. Núm.100, 30 de septiembre de 1813, pp. 109-113. La inquisición confundida. Valladolid 8 de agosto de 1813, M. Fr. Andrés del Corral. <http://prensahistorica.mcu.es/es/publicaciones/numeros_por_mes.cm $d$ ? anyo=1813\&idPublicacion $=1204>$ [Fecha de consulta: 27/01/2014] .

72. Periódico político y mercantil. Núm. 46. Jueves 18 de noviembre de 1813. Exposición del Reverendo obispo de Barbastro a las Cortes extraordinarias, pp. 187-189. 
unidos cordialmente á todos los hombres buenos de la península gocéis las ventajas de una Constitución justa y sabia... ${ }^{73}$.

En aquel mismo número, con redactado metafórico, en palabras de El Conciso, se daba cuenta también del traslado de dicho periódico a Madrid: "Señores hasta aquí llegó la carrera emigrante de El Conciso; pero aunque está para morir, alejado de las playas del embravecido Océano, espera su resurrección en las orillas del plácido Manzanares". ${ }^{74}$

El traslado de las Cortes a la capital de España significó el desplazamiento, desde Cádiz, de numerosos editores que seguían la estela del Gobierno. Fue el caso referido de El Conciso, que reapareció el 16 de enero de 1814. Otros periódicos que vivieron la misma experiencia fueron La Abeja española y El Tribuno del pueblo, entre los liberales, y El Procurador general de la nación y el Rey, entre los serviles. ${ }^{75}$ Según el Redactor General de España, el 16 de diciembre era la fecha indicada para la salida del Gobierno de la Regencia en dirección a Madrid, y la llegada a la capital se preveía para el día 5 de enero. ${ }^{76}$ Los acontecimientos se precipitaron, y el día 9, desde Madrid, se anunció la llegada de Luis Fernández de los Ríos, hermano del embajador de España en Londres, como custodio de los preliminares de paz entre Francia y España. El Duque de San Carlos, que había intervenido en les negociaciones del Tratado de Valençay, salió de la Corte a mediados de enero, en dirección desconocida, con una copia del decreto que las Cortes Generales habían aprobado el primero de enero de 1811, por el cual se declaraban nulos todos los actos y acuerdos adoptados por el Rey durante su cautividad y se confirmaba la voluntad de continuar la guerra mientras las tropas francesas no abandonasen el territorio peninsular. ${ }^{77}$

Con la llegada del nuevo año el periódico reusense, que sustituyó Año $6^{\circ}$ de la Libertad Española, por Año $7^{\circ}$, hacía referencia al itinerario seguido por el Gobierno en su desplazamiento a Madrid $^{78}$ :

73. Periódico político y mercantil. Núm. 77. Domingo 19 de diciembre de 1813, pp. 319322.

74. Periódico político y mercantil. Núm. 77. Domingo 19 de diciembre de 1813, p. 318

Biblioteca Virtual de Prensa Histórica. El Conciso. Núm. 2. Jueves 2 de diciembre de 1813, pp. 3-7. <http://prensahistorica.mcu.es/es/publicaciones/numeros_por_mes.cmd?anyo=1813 \&idPublicacion=3626> [Fecha de consulta: 28/01/2014]

75. SÁNCHEZ HITA, B. "La imprenta en Cádiz durante la guerra de la Independencia y su relación con la prensa periódica". En CANTOS CASENAVE, M.; DURÁN LÓPEZ, F.; ROMERO FERRER, A. (eds). La Guerra de Pluma... Vol. 1, pp. 31-111.

76. Periódico político y mercantil. Núm. 85. Lunes 27 de diciembre de 1813, p. 351. La cuestión del traslado y la reapertura de las sesiones en Madrid se empezó a discutir en la sesión de Cortes del 26 de noviembre de lo cual informó el mismo Periódico en el número 74, correspondiente al 16 de diciembre de 1813 en la página 305.

77. Periódico político y mercantil. Núm. 18. Martes 18 de enero de 1814, pp. 69-71.

78. Periódico político y mercantil. Núm. 3. Lunes 3 de enero de 1814, p. 11. 
Cuadro 2.

\begin{tabular}{|c|l|}
\hline DíA & \multicolumn{1}{|c|}{ LOCALIDAD } \\
\hline 19 & Jerez \\
\hline 20 & Utrera, descanso el día 21 \\
\hline 22 & Carmona \\
\hline 23 & Écija, descanso el día 24 \\
\hline 25 & Córdoba \\
\hline 26 & Pedro Abad \\
\hline 27 & Andújar \\
\hline 28 & La Carolina, descanso el día 29 \\
\hline 30 & Santa Cruz \\
\hline 31 & Manzanares, descanso el 1 de enero \\
\hline 2 & Madridejos \\
\hline 3 & Tembleque \\
\hline 4 & Aranjuez \\
\hline 5 & Madrid \\
\hline
\end{tabular}

Durante los días siguientes, las noticias centraron su atención en los actos de bienvenida que la capital dispensó a la Regencia. La información de la apertura de las Cortes, instaladas ya allí el 15 de enero, procedía de El Universal y concluía así:

¡Oh Padres de la Patria! Nuestras esperanzas sin duda van á corresponder con el suceso: grande es la empresa pero mayor es el honor y la gloria. ¡Que podrá igualar a la satisfacción de sacar a las ciencias de entre tinieblas, hacer de cada soldado un héroe, poblar los desiertos, y hermosear los eriales campos, promover el paralizado comercio, y dar la actividad que necesitan las amortiguadas artes y manufacturas!... Así os contemplamos como el astro matutino... ${ }^{79}$.

A finales de enero de 1814 el Periódico se hizo eco de un artículo que había difundido el día 21 El Redactor General de España, en el apartado Variedades, que se refería a la tiranía y que era un alegato en favor de la Constitución:

79. Periódico político y mercantil. Núm. 28. Viernes 28 de enero de 1814. pp.110 y 111. Hemeroteca Municipal Madrid (HMM). El Universal. Núm. 15. Sábado 15 de enero de 1814, p. 60. <http://www.memoriademadrid.es/fondos/OTROS/Imp_9649_hem_universal_18140115. pdf $>$ [Fecha de consulta: 28/01/2014]. 
no quiere (la Constitución) esclavos o bestias de carga que se dejen conducir aquí y allí según el capricho de uno o de muchos. Y concluía: Si algún artículo debe ser reformado, suspéndase, pasado el tiempo de la ley, anúlese en buena hora; pero todo esto hágase conforme a la ley misma... defendamos la Santa Constitución según que hemos jurado, no seamos PERJUROS. ${ }^{80}$

Llegado el sábado 12 de febrero, en su apartado de "noticias del Reyno", el Periódico transcribió el decreto aprobado por las Cortes el día 2. En sus trece artículos determinaba el programa y solemnidades a seguir ante la inminente liberación y regreso de Fernando VII y el protocolo que correspondía a su dignidad. ${ }^{81}$

Una semana después, el Periódico detalló los incidentes ocurridos en la sesión del Congreso del día 3, cuando el diputado sevillano Juan López Reyna defendió el absolutismo del Rey, ganándose los correspondientes abucheos. ${ }^{82}$ Dos días más tarde, abría la edición el artículo Conjuración contra la libertad Nacional, firmado por "El sevillano inexorable", R. Z. y publicado en la Gazeta Provincial de Valencia. Comentaba el atrevimiento del ya ex-diputado López Reyna en expresar su servilismo precisamente el día en que las Cortes aprobaban las solemnidades con que Fernando VII debía jurar la Constitución. Justificó el término conjuración en tanto que cabía la posibilidad de que en los planteamientos defendidos por aquél hubiese más personas implicadas. El hecho es que corrían insistentes rumores sobre la posibilidad de que las garantías constitucionales estuviesen en peligro -alimentados por la prensa reaccionaria (El Procurador General de la Nación y del Rey)-, los cuales comenzaron a contemplarse con preocupación. Desde sectores absolutistas se gestaban todo tipo de intrigas con tal de desacreditar al gobierno de la nación. Precisamente, el suplemento de El Procurador publicado el 10 de febrero de 1814 había sido examinado por la "Junta Censoria de la provincia" a instancias de la Regencia, por presuntas injurias que Luis Audinot ${ }^{83}$ había vertido contra miembros de ésta, del Gobierno y del Congreso, en declaraciones realizadas al comandante de armas de Granada

80. Periódico político y mercantil. Núm. 31. Lunes 31 de enero de 1814. pp. 122 y 123. Publicado por el Redactor General de España el 21 de enero de 1814 en el apartado de Variedades.

81. Periódico político y mercantil. Núm. 43. Sábado 12 de febrero de 1814, pp.169-172.

82. ARTOlA GAlleGO, M. Los orígenes..., p. 712. También en CUENCA TORIBIO, M. La Guerra..., p. 373.

83. GIL NOVALES, A. Prensa, guerra..., p. 29. Luis Audinot en realidad se Ilamaba Jean Barteau y al parecer había sido fraile, soldado y criado de la Duquesa de Osuna; había fingido ser un general francés enviado por Napoleón para establecer la República Iberiana. El Procurador sirvió de portavoz a sus descalificaciones en las cuales se vieron implicados Agustín Argüelles y otros personajes. Después de retractarse acabó suicidándose. TORENO, Conde de. Noticia de los principales sucesos ocurridos en el Gobierno de España desde el momento de la insurrección en 1808, hasta la disolución de las CORTES ordinarias en 1814; por un español residente en París. Barcelona: Librería de Narciso Oliva, 1820, pp. 99-104. 
el 24 de enero. ${ }^{84}$ Permite valorar el nivel de exaltación al que se había llegado, el artículo comunicado por el Periódico de Reus al Redactor General de España del día 23 de febrero, en el que se podía leer: "El Procurador, que incluye la delación de Oudinot, es un papel horrible, capaz de regar con la sangre de sus hijos este suelo invicto: ¡Se sirve así a la patria! ¿Qué política aconsejó esta publicación? La de un tigre ansioso de sangre humana". ${ }^{55}$

En los números 86 y 87 correspondientes a los días 27 y 28 de marzo, en dos entregas, el Periódico transcribió el artículo que El Universal había publicado el 19 del mismo mes, en conmemoración del aniversario de la Constitución. ${ }^{86} \mathrm{Al}$ final del segundo de dichos números, en página sin numerar, quedaba detallado el itinerario que seguiría Fernando VII en su desplazamiento desde la ciudad de Girona hasta Valencia.

\section{CuAdro 3.}

\begin{tabular}{|l|c|}
\hline Fecha e itinerario & $\begin{array}{c}\text { Horas de } \\
\text { viaje }\end{array}$ \\
\hline Lunes 28 de marzo. De Girona a Calella & 10 \\
\hline Martes 29 de marzo. De Calella a Mataró & 5 \\
\hline Miércoles 30 de marzo. De Mataró a Molins de Rei & 8 \\
\hline Jueves 31 de marzo. De Molins de Rei a El Vendrell & 8 \\
\hline Viernes 1 de abril. De El Vendrell a Reus & 9 \\
\hline Sábado 2 de abril. De Reus a El Perelló & 9 \\
\hline Domingo 3 de abril. De El Perelló a Sant Carles de la Ràpita & 9 \\
\hline Total días & 58 \\
\hline
\end{tabular}

Igualmente se reprodujo la distribución de los acompañantes del Rey y de sus invitados por mesas, así como el servicio de mesa y las provisiones de boca. ${ }^{87}$

84. AUDINOT, L. Apéndice al Procurador General de la Nación y del Rey, 10 de febrero de 1814. <http://galiciana.bibliotecadegalicia.xunta.es/es/consulta/registro.cmd?id=3525> [Fecha de consulta: 30/01/2014]. Se trata de la copia literal de la manifestación voluntaria que hizo D. Luis Oudinot [i.e. Audinot], general francés, preso en Baza y trasladado a Granada, al comandante de armas de dicha ciudad D. Pedro Cortés, que en su momento editó en Madrid la imprenta Dávila. Hay que señalar que los incidentes con esta publicación se sucedieron con frecuencia desde este momento.

85. Periódico político y mercantil. Núm. 65. Domingo 6 de marzo de 1814, pp. 257-259.

86. HMM. El Universal. Núm. 78. Sábado 19 de marzo de 1814, p. 310. <http://www.memoriademadrid.es/fondos/OTROS/Imp_10644_hem_universal_18140319.pdf> [Fecha de consulta: 30/01/2014].

87. Periódico político y mercantil. Núm. 86. Domingo 27 de marzo de 1814, p. s.n. 
El Monarca, según una carta fechada el 26 que publicó el Periódico, llegó a Girona el día 24 acompañado por su tío Don Antonio y por el Duque de San Carlos. Su hermano, el infante Don Carlos, había quedado inicialmente retenido, pero había sido liberado en Bàscara, cerca del río Fluviá. Tropas francesas y españolas, al mando de los generales Louis Suchet y Francisco Copons respectivamente, fueron testigos de su puesta en libertad. Además, la carta describía el júbilo de los gerundenses por la presencia del Rey.

Siguiendo el calendario previsto, Fernando VII llegó a Reus el primero de abril en loor de multitudes, y un coro de músicos le obsequió con una canción. El Periódico, naturalmente, lo publicó en un panegírico en el que la palabra Constitución ocupaba un lugar relevante. El día 3, a las 9,30 de la mañana, el Rey abandonó la ciudad, pero no en dirección a El Perelló, como estaba previsto. Sin dejar de ir a Valencia, prefirió dirigirse antes a Zaragoza, por lo que tomó el camino hacia Poblet, donde pernoctó. Seguidamente prosiguió hacia Lleida y la llegada a Zaragoza tuvo lugar el día $6 .^{88}$

La historiadora María del Carmen Abad ha detallado el recorrido seguido por Fernando VII hasta Valencia después de abandonar Zaragoza el día 11. Aquel mismo día Ilegó a Daroca; el 12, a Villafranca del Campo; el 13, a Teruel; el 14, a Sarrión; el 15, a Segorbe, y, finalmente, el sábado día 16 alcanzó la capital valenciana. ${ }^{89}$

Mientras el Monarca prolongaba su marcha hacia la capital se gestaba el Manifiesto de los Persas. A mediados de abril, sesenta y nueve diputados, a la cabeza de los cuales se encontraba Bernardo Mozo de Rosales, rechazaban la Constitución de 1812 y proponían la convocatoria de unas nuevas cortes, estamentales, que permitieran una monarquía regulada por las antiguas leyes. Se trataba de reformar la Monarquía tradicional sin cuestionar sus principios doctrinales básicos. El objetivo era inducir a Fernando para que, con un golpe de estado, pusiera fin a las reformas constitucionales ${ }^{90}$.

88. Periódico político y mercantil. Núms. 92, 93 y 94. Sábado 2, domingo 3 y lunes 4 de abril de 1814. pp. 369, 373-375 y 377-378. Recordemos que un estudio completo de su presencia lo tenemos en GIMENO PUYOL, D. "Entre la paz y las polémicas...", pp. 259-277.

ABAD GIMENO, M. del C. "La entrada de Fernando VII en Zaragoza". Cuadernos de Historia Jerónimo Zurita. Núms. 16-18, (1963-1965), pp. 331-343. Según Abad (citando a Pedro Aguado Bleye) el motivo del cambio de recorrido era para no seguir el camino indicado por la Regencia. La conjura estaba en marcha.

89. ABAD GIMENO, M. del C. "La entrada de...", pp. 331-343.

90. VARELA SUANZES-CARPEGNA, J. "La teoría constitucional en los primeros años del reinado de Fernando VII el manifiesto de los persas y la representación de Álvaro Flórez Estrada". En Estudios dieciochistas en homenaje al profesor José Miguel Caso González. Vol. 2 (1995), pp. 417-426. WILHEMSEN, A. "El Manifiesto de los persas, una alternativa ante el liberalismo español". Revista de Estudios Políticos. Núm. 12 (1979), pp. 141-162. 
El 4 de mayo el Periódico transcribió un artículo del Redactor General de España, que transmitía cierto desasosiego ante la tardanza del Rey en comparecer ante el Congreso para jurar la Constitución:

Fernando, el virtuoso Fernando, hace más de un mes que entró en España, y aun no hemos tenido la dicha de verle presentarse en el augusto Congreso... ¿Qué significa esta larga detención en Valencia, con que tiene inquietos y vacilantes los corazones de todos sus conciudadanos? Habrá algún plan execrable de parte de los numerosos enemigos de nuestra libertad, para destruirla?... Si logran los malvados seducir el corazón de nuestro Monarca inspirándole sentimientos contrarios à la Constitución, nos la dexaremos arrancar impunemente? ¿Cederemos cobardemente el campo de la libertad sin espirar primero anegados en nuestra sangre...? No, jenemigos de la patria...! no... Si son necesarias victimas para conquistar nuestra libertad las habrá, porque la libertad es ya la diosa de los españoles. ${ }^{91}$

Dos semanas más tarde, el 18 de mayo, el Periódico veía la luz por última vez. La noticia más relevante de aquel postrer número, publicada por la Gazeta de Valencia, aludía al homenaje que los ciudadanos de Madrid habían realizado a los restos de los generales Luis Daoiz y Pedro Velarde. ${ }^{92}$ Dos días antes había presentado, como artículo principal, unos comunicados que la Diputación Provincial y el Ayuntamiento Constitucional de Cádiz habían firmado el 3 de mayo. Diputados y regidores mostraban su sorpresa ante el retraso que mostraba el Monarca en llegar a Madrid y jurar la Constitución. Sin cortapisas mostraban la inquietud por la demora, y en cierto modo temían lo que sucedería pocos días después. ${ }^{93}$

No debe sorprender que, dado los tiempos convulsos que se vivían y la ideología que lo impregnaba, el diario fuera protagonista de intensas polémicas, algunas de las cuales motivaron la publicación de separatas. En la titulada Amonestación político christiana a los subscriptores y lectores del diario de la Villa de Reus, que les hace un patricio sensible a los males que la amenazan, el reaccionario patricio sensible J.T.C.B., autor del documento, lanzaba un duro ataque contra los redactores del Periódico. Les consideraba merecedores de castigo por irreligiosidad, por corrupción de costumbres, por infidelidad, por falta de respeto a Dios y a sus ministros, por instigadores de las pasiones más brutales. Estas transgresiones eran resultado de las doctrinas pestilenciales que insertaban en sus páginas. La respuesta, que llegó a través del artículo Al impolítico-cristiano

91. HMM. Redactor General de España. Lunes 25 de abril de 1814, pp. 701-702. <http:// www.memoriademadrid.es/fondos/OTROS/Imp_17641_hem_ah_7-6_18140425.pdf> [Fecha de consulta: 3/02/2014]. Periódico político y mercantil. Núm.124, Miércoles 4 de mayo de 1814, pp. 502-504.

92. Periódico político y mercantil. Núm. 138. Miércoles 18 de mayo de 1814, pp. 558-560.

93. Periódico político y mercantil. Núm. 136. Lunes 16 de mayo de 1814, pp. 549-551. 
amonestador autor del libelo contra los administradores de la casa de caridad de la Villa de Reus, Los redactores de su diario, y otros responde El amigo de los pobres $^{94}$, ensalzaba la ideología liberal, enaltecía a los representantes de la nación en las Cortes y en definitiva rechazaba sus alegatos. El autor, para reprobar el escrito del patricio, utilizó la primera parte del epigrama, titulado Ad Martialem, que escribió el poeta galés John Owen: Dicere de rebus personis parcere nosti. ${ }^{95}$

Otra controversia fue iniciada el 17 de noviembre por "El militar ciudadano", que firmó el artículo No me ha gustado, que una semana después en un folleto impreso en Tarragona, en la imprenta de Antonio Brusi, mereció la réplica de "El español sensato". El militar ciudadano se mostraba en desacuerdo con los argumentos que esgrimía Arthur Wellesley, Duque de Ciudad Rodrigo, cuando fue interpelado por el gobierno, con relación a los hechos acaecidos en la toma de San Sebastián. Se refería a la defensa que Wellesley hizo del general Thomas Graham, comandante del ejército sitiador, en el sentido que, de todas las ciudades que había tomado por asalto, no conocía ninguna que no hubiera sido saqueada. El español sensato criticaba al redactor del diario por autorizar la publicación del artículo y contradecía al ciudadano militar, en tanto que justificaba los excesos que se originaban en la ocupación de las plazas fuertes, sobre todo cuando se producía derramamiento de sangre; tildaba de prudente la intervención, ante la nación, de lord Wellesley, anteponiendo los méritos y la dignidad del general a la suerte que corrieron los habitantes guipuzcoanos; y terminaba su mensaje con un soneto en el que, además de ensalzar el valor de los catalanes y criticar al movimiento liberal, descalificaba al editor del Periódico. ${ }^{96}$

94. Ambos folletos son de 1813, el primero se imprimió en Tarragona, en el taller tipográfico de Garriga y el segundo se editó en Reus, en la imprenta de José Rubió y se comercializaba al precio de 6 quartos.

95. El epigrama completo sería: Dicere de rebus, personis parcere nosti, Sunt sine felle tui, non sine melle sales. Con él, Jaume Ardévol, editor del periódico y seguramente quién se ocultaba bajo el seudónimo de El amigo de los pobres, con finura le respondía que se podía reprobar aquello que no estaba bien, pero al mismo tiempo se debía ser indulgente con quien lo había hecho. Que el autor conociera esta cita, es una buena muestra de su capacidad intelectual. John Owen (c.1560-1622) fue un epigramista galés, experto en lengua latina, que siguió el estilo del poeta Marcial. La primera edición de este epigrama se publicó en Epigrammatum libri tres. Autore Ioanne Owen Britanno: Noui collegii Oxoniensis nuper socio, Londini: apnd [sic] loannem Windet, sumptibus Simonis Watersonu, 1606. Agradezco esta información a J.F. Alcina y a A. Isla.

96. Periódico político y mercantil. Núms. 45, 46, 56, 80. Miércoles 17 , jueves 18 y miércoles 22 de diciembre de 1813, pp. 183-185, s/n y 331-333. En la toma de San Sebastián, el 31 de agosto de 1813, la ciudad fue incendiada y saqueada por parte de los aliados. Sobre este tema consultar LAFON, J. M. "San Sebastián 1813. Bloqueos, sitios y destrucción". En BUTRON PRIDA, G.; RÚJULA LÓPEZ, P. (coords.). Los sitios en la Guerra de la Independencia: la lucha en las ciudades. Cádiz: Ed. Sílex-Universidad de Cádiz, 2012, pp. 335-356. SAN JOSÉ SEIGLAND, C. "Precisiones sobre el sitio y asalto a San Sebastián en agosto de 1813". Boletín de estudios históricos sobre San Sebastián, Núm. 41 (2007), pp. 471-506. MURUGARREN ZAMORA, L. San Sebastián incendiada: británicos y portugueses. Donostia: Sociedad Guipuzcoana de Ediciones y Publicaciones, 1993. MARTíNEZ RUIZ, J. "La Guerra de la Independencia asalto y 
Una semana más tarde "Un Inglés" y "J. de H." terciaban en la polémica. El primero mantenía una cierta neutralidad. Con un estilo educado, aunque comprendía que después de semanas del asedio los atacantes quisieran resarcirse de los peligros con el saqueo, sugería que para evitar mayores desmanes el asalto final lo protagonizaran las tropas nacionales. Mientras que el segundo calificaba al artículo del militar ciudadano de malicioso y perjudicial. En defensa del general Graham, entre otros razonamientos, el "inglés" esgrimía que el elevado número de bajas de oficiales en el ejército sitiador -180 oficiales muertos o heridos- había impedido contener a la soldadesca. Por último a finales de diciembre, el militar ciudadano arremetió nuevamente en el Periódico contra el español sin seso, que en Tarragona quiso llamarse sensato. De las cuatro páginas de que constaba el diario, tres se dedicaron a su discurso, incluyendo en la última un poema de cuatro estrofas en octavas reales, dedicado a la Libertad. ${ }^{97}$

El segundo periódico liberal de la ciudad, el Eco de Reus, publicó su primer número el 16 de abril de 1814 y su recorrido no fue más allá del 14 de mayo. Se imprimía dos días a la semana (generalmente el martes y el sábado), ocupaba cuatro páginas, costaba seis "quartos" el ejemplar suelto y siete reales la subscripción mensual, y era editado en la "imprenta de los Amigos de la Constitución" por Joaquín Artigas. Debajo de la fecha tenía escrito: "Año $7^{\circ}$ de la Regeneración Española, y $3^{\circ}$ de la Constitución". Hay que referir que el día anterior a su aparición se imprimió un prospecto que justificaba la edición sobre la base de que la libertad de imprenta no era tal, a pesar del decreto que la garantizaba. En los contenidos que desarrolló, durante las cuatro semanas que estuvo en circulación, fue perseverante en la defensa de la Constitución. ${ }^{98}$ De hecho, el artículo que abría el diario se titulaba Constitución y el 19 de marzo, aniversario de la Carta Magna, lo había editado el Diario de Palma y se extendía a lo largo de dos páginas y media. ${ }^{99}$ En el número 4, reaparecía "El militar ciudadano", que redactó un supuesto diálogo entre un militar y su asistente, naturalmente con el tema constitucional de fondo. Refiriéndose al posicionamiento del monarca decía el militar:

Pues supongamos ahora un imposible y para entrar en materia figuremonos el caso no solo como posible, sino como verosimil: Supongamos que nuestro deseado Rey Fernando, rodeado de malvados, mal aconsejado, alucinado en fin, su entendimiento, reusase reconocer y jurar la constitución. ¿Qué deveriamos hacer entonces?

La respuesta del asistente fue que habría que reprenderle y pedirle con energía que no se burlase de las esperanzas abrigadas por su pueblo durante seis

destrucción de San Sebastián (1808-1813)". Boletín de la Real Sociedad Bascongada de Amigos del País. Tomo 46, núm. 1-2 (1990), pp. 175-196.

97. Periódico político y mercantil. Núms. 52 y 55. Miércoles 24 y sábado 27 de noviembre de 1813, pp. 217 y 227-230, respectivamente.

98. ANGUERA NOLLA, P. Comportament polític..., p. 36.

99. Eco de Reus. Núm. 1. Sábado 16 de abril de 1814, pp. 1-3. 
años. Y si a pesar de ello se obstinase, se le tendría que admitir la abdicación. ${ }^{100}$ El resto de la publicación se dedicaba a noticias nacionales y extranjeras. Se hizo referencia a acontecimientos bélicos y a las sesiones de Cortes. Contuvo también artículos de opinión, así como poemas ensalzadores de la Constitución, del rey Fernando y de la ideología liberal. Finalmente, incluyó réplicas al periódico local de signo servil el Centinela.

Al margen de que la cuestión política ocupara en sus páginas un lugar de privilegio, el ejemplar del 3 de mayo reproducía las reflexiones de un colaborador relativas a la importancia que tenia la educación para que los ciudadanos hicieran un buen uso de las libertades adquiridas. Fue una de las pocas ocasiones en que la preocupación por la pedagogía adquirió protagonismo en alguno de los periódicos liberales. ${ }^{101}$

\section{La restauración absolutista}

Con el golpe de estado del 4 de mayo de 1814, Fernando VII decretó el cierre de las sesiones de las Cortes Constitucionales:

...declaro que mi real ánimo es no solamente no jurar ni acceder a dicha constitución ni á decreto alguno de las Cortes generales y extraordinarias, y de las ordinarias actualmente abiertas... Y desde el día que este mi decreto se publique, y fuere comunicado a la sazón al presidente que a la sazón lo sea de las Cortes que actualmente se hallan abiertas, cesaran estas en sus sesiones... ${ }^{102}$.

La anulación de los decretos aprobados en el marco de la Constitución significó la suspensión por Real Decreto de 1815 de todos los diarios editados en España, a excepción de la Gazeta y el Diario de Madrid, y el Diario de Barcelona, así como la reinstauración de la Inquisición, que por el decreto de 22 de julio de 1815 condenó como contrarias a la religión y al Estado las obras y hojas impresas editadas mientras estuvo abolida la institución:

Sabed: Que á nuestra noticia ha llegado, y á toda España es bien notorio, que entre los males que nos atrajo la invasión enemiga en 1808 y la ausencia y cautividad de nuestro amado Monarca, no ha sido el menor la libertad de pensar y escribir con tal desafuero que por el espacio de cinco años se vio nuestra piadosa y católica nación inundada de folletos, periódicos, papeles volantes y escritos perversos que andaban en manos de todos con ruina de sus almas [...] hemos venido también en mandar, con acuerdo y parecer de los Señores del Consejo de S.M. de la santa

100. Eco de Reus. Núm. 4. Martes 26 de abril de 1814, p. 14.

101. Eco de Reus. Núm. 6. Martes 3 de mayo de 1814, pp. 21-23.

102. Gaceta Extraordinaria de Madrid. Núm. 70. Jueves, 12 de mayo de 1814, pp. 515-521. 
y general Inquisición, se recojan y entreguen al Santo Oficio hasta que sean examinadas y calificadas todas las que se incluyen en este edicto por lista alfabética prohibiendo su lectura y retención... Por tanto queriendo prevenir con oportuno remedio el daño que de la lectura de dichos libros, folletos y papeles se puede seguir á los fieles y a la religión católica... hemos mandado se prohíban i recojan respectivamente, para que ninguna persona los pueda vender, leer ni retener impresos o manuscritos, en cualquier lengua o impresión que lo estén, pena de excomunión mayor, y de doscientos ducados para gastos del Santo Oficio y demás establecidas por derecho. ${ }^{103}$

En este decreto y en otros posteriores ( 1 de marzo de 1817 y 15 de enero y 29 de mayo de 1819) quedaban incluidos los diarios e impresos con connotaciones políticas y religiosas. La vorágine inquisitorial se llevó por delante las Abejas, los Amigos, las Auroras, los Catecismos, los Duendes y un largo etcétera de periódicos. Bajo el manto de salvaguardar la ortodoxia religiosa se escondía un control político e ideológico, que alcanzó hasta los lugares más recónditos de la geografía peninsular.

El Periódico había publicado algunos folletos como la Inquisición confundida, escrito por fray Andrés del Corral, y la copia de la Representación del obispo de Barbastro dando gracias por la abolición de la Inquisición, a los que ya nos hemos referido, y en el número 71 editaba la Proclama a los labradores. En dicho comunicado, un hacendado labrador de Reus ensalzaba la importancia de la agricultura como actividad económica, reivindicaba el derecho a la libertad ante la invasión francesa y describía los atropellos sufridos por la población por esta causa, al tiempo que subrayaba el nuevo concepto social: el de ciudadano. El hacendado labrador analizaba las dos tendencias ideológicas del momento: la ser-vil [sic] y la liberal. Servil era sinónimo de servidumbre o esclavitud, y designaba al hombre indigno de ostentar la cualidad de ciudadano. Los serviles eran los enemigos de la nación a los que había que combatir: eran serviles aquellos diputados que atentaban contra la Constitución y los frailes que iban predicando por los pueblos, ocupándose de las cuestiones temporales, fomentado partidos y confundiendo las ideas y olvidándose de su labor espiritual. Unos y otros los consideraba más enemigos que los mismos franceses. Como muestra del poder señorial se refería a algunas localidades del Camp de Tarragona, como Constantí, Mont-roig y Riudoms, cuyos habitantes habían sufrido la represión feudal.

En cambio, los liberales eran quienes habían redactado la Constitución, y gracias a ella los campesinos se podían sustraer a la abominable obediencia que hasta este momento habían debido a la nobleza. Ser liberal equivalía a ser hom-

103. MARTIN DE BALMASEDA, F. Decretos del Rey Don Fernando VII año segundo de su restitución al Trono de las Españas. Vol. II. Imprenta Real, 1819. Edicto de la suprema y general Inquisición de 22 de julio de 1815, pp. 503-517. 
bre bueno y justo, amante del orden y de la Patria. Los liberales eran los defensores de los derechos del pueblo, los que habían abolido los señoríos y convertido a los campesinos en ciudadanos.

Los últimos párrafos los dedicaba a Fernando VII, a quien consideraba un monarca constitucional. El labrador, sirviéndose de la figura retórica de percontatio, ponía en boca del rey aquellas palabras que a todo defensor de la Constitución le gustaría oir:

¿Qué hará Fernando? [una vez que haya regresado]. Adorar su amada patria, abrazar a todos los Españoles, prosternarse delante de la Constitución, jurar la observancia de este Sagrado Libro... Dichoso tu si sabes olvidar que naciste Rey, pero habiendo sido esclavo el valor y generosidad de tu pueblo debiste otra vez el Reynar. Dichoso tu si no olvidas que la Constitución ha sido hecha para todos los Españoles, pero que abraza muy particularmente á nosotros los labradores familia la mas numerosa de la Monarquía. ${ }^{104}$

En marzo de 1814, el mismo Periódico anunciaba la puesta en circulación de Antidoto verdadero contra la doctrina de Tres Proposiciones, texto que Jaime Cabruja, presbítero de Reus, había redactado contra el Dictamen sobre el Tribunal de la Inquisición. El autor de este último, Antonio José Ruiz de Padrón, abad de Villlamartín de Valdeorras y diputado por las Islas Canarias, lo había presentado en las Cortes el 18 de enero de 1813, abogando por la disolución del Santo Oficio. ${ }^{105}$

A pesar de que el procedimiento afectó a los citados artículos, cabe decir que en ninguno de los edictos expedidos por la Suprema y General Inquisición, referentes a publicaciones prohibidas, no consta el diario al que, sin embargo, la oleada absolutista hizo desaparecer ${ }^{106}$. Su editor, Jaume Ardévol, a causa de los contenidos publicados en el Periódico, fue encausado y encerrado durante quin-

104. Periódico político y mercantil. Núm. 71. Sábado 12 de marzo de 1814, pp. 282-288. GALENDE DÍAZ, J. C. "Documentos inquisitoriales para la historia de la provincia de Tarragona". Quaderns d'Història Tarraconense. Núm. 9 (1990), pp. 163-171.

105. Periódico político y mercantil. Núm. 85. Sábado 26 de marzo de 1814, p. 344. CABRUJA, Jaime. Antidoto verdadero contra la doctrina de Tres Proposiciones. Reus: oficina de Rubió, 1813. Tenía 19 pliegos, en cuarto y se vendía a 10 reales de vellón. En Tarragona se podía adquirir en el librero Brusi y en Reus en la oficina del mismo periódico, en la calle Jesús.

RUIZ DE PADRÓN, A. Antonio J. Dictamen sobre el Tribunal de la Inquisición. Cádiz: Imprenta Tormentaria, 1813.

106. Apéndice al Índice General de los Libros Prohibidos que comprende los edictos de la Inquisición posteriores al de 25 de agosto de 1805 hasta el de 29 de mayo de 1819 (último que se publicó) y los decretos de Su Santidad y de la Sagrada Congregación del Índice hasta el 3 de marzo de 1846. Madrid: Imprenta de D. José Félix Palacios, 1848.

Sin embargo, Manuel Gómez Imaz en la ficha 265, referida a este periódico, asegura que la Inquisición lo incluyó en su edicto de 22 de julio de 1815, ordenando su retirada y prohibiendo su lectura bajo pena de excomunión. 
ce meses en los calabozos de la torre de Pilatos en Tarragona, posteriormente sería absuelto por la Audiencia de Barcelona. ${ }^{107}$

Así terminó la aventura liberal de una Prensa que debería esperar hasta 1820 para que, con la recuperación de la Constitución de 1812, adquiriese nuevamente vigor, aunque, como sabemos, sólo por un breve período.

La actividad política y periodística de Ardévol no se reanudó hasta la llegada del Trienio Liberal. En 1820 fue nombrado síndico procurador del ayuntamiento de Reus y en mayo de 1822 actuaba como secretario de la recién creada Diputación Provincial de Tarragona ${ }^{108}$; ese mismo año fundó la Diana Constitucional Política y Mercantil de la villa de Reus, un periódico también de corte liberal que, con la firme intención de defender el sistema constitucional, tomaba el relevo del Periódico. ${ }^{109}$

\section{Conclusiones}

Históricamente Reus siempre se ha mostrado como una ciudad combativa en la lucha ideológica y con una marcada personalidad en el momento de alinearse al lado de una u otra opción. Durante la guerra de Sucesión, se decantó del lado del archiduque Carlos; a comienzos del siglo XIX, con la monarquía secuestrada y en pleno auge del movimiento liberal, no dudó en ondear la bandera del progresismo; insistió en ello durante el Trienio Liberal; y de la mano del general Joan Prim participó en los episodios convulsos que dieron como resultado la Revolución Gloriosa de 1868.

El hecho de que en el breve espacio de tiempo que media entre 1813 y 1814 llegasen a publicarse en Reus hasta tres periódicos (de signo diverso, es verdad) es buena muestra del interés que tenía la ciudad por la actividad política, así como del ansia de sus ciudadanos por conocer cómo cambiaban los tiempos y se transformaba la sociedad.

El breve recorrido del Periódico, del 4 de octubre de 1813 al 18 de mayo de 1814, no fue óbice para que ocupara un lugar relevante en el panorama de la prensa liberal catalana y española. La personalidad política de su editor, Jaume Ardévol, quedó reflejada en sus páginas a pesar de los titubeantes inicios del sistema constitucional. La presencia de artículos procedentes de distintas fuentes: Aurora patriótica mallorquina, Gaceta de Madrid, Gazeta de Valencia o El Redactor General de Cádiz, es prueba evidente de que Reus no deseaba permanecer ajena a lo que se estaba gestando en cualquiera de las capitales españolas

107. ELÍAS DE MOLINS, A. Diccionario biográfico..., pp. 109 y 110.

108. JORDÀ FERNANDEZ, A. Orígens de la Diputació de Tarragona (1820-1840). Tarragona: Diputació de Tarragona, 2008, p. 91.

109. ARNABAT MATA, R. Diana Constitucional Política y Mercantil de la villa de Reus en el marc del Trienni Liberal (1822). Reus: Associació d'Estudis Reusencs, 2007, p. XXVI. 
y europeas, donde se dirimía el futuro, con el telón de fondo del ejército de Napoleón en retirada.

Gracias al Periódico político y mercantil, Reus conoció noticias nacionales y del extranjero: la apertura de las Cortes, las discusiones parlamentarias y su resultado, la capitulación de las últimas plazas peninsulares ocupadas por las tropas francesas y su ulterior salida, la retirada del ejército napoleónico de los diversos frentes europeos, el regreso de Fernando VII, el entusiasmo despertado ante su llegada y la cautela generada por su todavía no demostrado constitucionalismo. Sus páginas, con amplios debates, se convirtieron en escenario del combate progresista contra los grupos reaccionarios. En ellas tuvieron cabida exaltadas proclamas favorables a la Constitución frente a la extremada defensa de la tradición.

La inclusión de estos escritos en los decretos inquisitoriales es una prueba del peligro que, para el régimen absolutista, podían representar como agente difusor de las nuevas ideas y una muestra de la capacidad de represión de la jerarquía estamental. Las noticias de carácter político y bélico (según se ha dicho repetidas veces) se vieron completadas por otras de economía y por avisos donde la vida cotidiana de la población se hacía presente. Con la publicación de artículos procedentes de otros diarios, algunos de ellos quizá desaparecidos, el Periódico representa, además, una fuente de información nacional de extraordinaria importancia. La defensa de la Constitución, a través de la prensa, se reanudará con la instauración del Trienio Liberal, en cuyo transcurso Jaume Ardévol, como acabamos de decir, volvería a la palestra con la Diana Constitucional Política y Mercantil de la villa de Reus.

\section{Bibliografía}

AGUADÉ BRUIX, E. Bibliografia reusenca fins al 1900. Reus: Associació d'Estudis Reusencs, 1998.

AGUILAR PIÑAL, F. La prensa española en el siglo XVIII. Diarios, revistas y pronósticos. Cuadernos Bibliográficos. Madrid: CSIC, 1978.

ANGUERA NOLLA, P. Comportament polític $i$ actituds ideològiques al Baix Camp: 1808-1868. Reus: Associació d'Estudis Reusencs, 1983.

ARTOLA GALLEGO, M. "Cortes y constitución de Cádiz". En ESCUDERO, José A. (dir.). Cortes y Constitución de Cádiz, 200 años. Madrid: Espasa Libros, 2011, pp. 3-19.

CAHNER, M. Literatura de la revolució i la contrarevolució (1789-1849). La Guerra del Francès, 2 vols. Barcelona, 2002.

CANTOS CASENAVE, M.; DURÁN LÓPEZ, F.; ROMERO FERRER, A. (eds.). La Guerra de Pluma. Estudios sobre la prensa de Cádiz en el tiempo de las Cortes 
(1810-1814), 3 vols. Cádiz: Servicio de Publicaciones de la Universidad de Cádiz, 2006-2008.

ELIAS DE MOLINS, A. Diccionario biográfico y bibliográfico de escritores y artistas catalanes del siglo XIX, 2. vols. Pamplona: Analecta, 2000.

FÀBREGAS ROIG, J.; NAVAIS ICART, J. (coords.). Premsa i societat. Aspectes polítics econòmics i socials. Reus: Arola Editors, Publicacions URV, Centre de Lectura, 2013.

GIL NOVALES, A. Prensa, guerra y revolución. Los periódicos españoles durante la Guerra de la Independencia. Madrid: CSIC - Ediciones Doce Calles, 2009.

GÓMEZ IMAZ, M. Los periódicos durante la guerra de la Independencia (18081814). Madrid, 1910.

GUILLAMET LLOVERAS, J. Els orígens de la premsa a Catalunya. Catàleg de periòdics antics (1641-1833). Barcelona: Arxiu Municipal de Barcelona, 2003.

MARTínEZ SHAW, C. El Siglo de las Luces. Madrid: Temas de Hoy, 1996.

PIZARROSO QUINTERO, A. (coord.). Historia de la prensa. Madrid: Centro de Estudios Ramón Areces, 1994.

SAIZ GARCIA, M. D. Historia del Periodismo en España. Los orígenes. El sig/o XVIII. Madrid: Alianza Editorial, 1995.

SÁNCHEZ HITA, B. Los periódicos del Cádiz de la Guerra de la Independencia (1808-1814).Catálogo comentado. Cádiz: Colección bicentenario 1812. Núm. 9, Diputación de Cádiz, 2008. 